\title{
EN TORNO A DONANTES Y ME FECIT EN LOS BORDADOS MEDIEVALES: LA ESTOLA DE SAN NARCISO Y EL ESTANDARTE DE SAN OT*
}

\author{
Verónica Carla Abenza Soria ${ }^{1}$ \\ Consejo Superior de Investigaciones Científicas, CCHS-IH
}

\begin{abstract}
Los bordados medievales de la Estola de San Narciso y el Estandarte de San Ot han suscitado cierto interés de los investigadores por su contenido epigráfico y figurativo. Al incorporar inscripciones con me fecit y un retrato de donantes, se inscriben en la problemática para interpretar si estos recursos aluden al artista o al comitente, en su caso, una mujer. Por ello, la atención se ha centrado fundamentalmente en identificar al sujeto histórico responsable de su autoría. Contrariamente, este artículo pretende indagar en el sistema social y de creencias del contexto en el que ambos fueron creados. El objetivo es entender, a su vez, cómo cuestiones como la creación colectiva, el anonimato o el culto a los santos pudieron influir en las estrategias para dar forma a esas mismas imágenes e inscripciones.
\end{abstract}

Palabras Clave: Estola de San Narciso; Estandarte de San Ot; bordados medievales ibéricos; artistas y promotoras medievales; culto a los santos; me fecit; retratos de donantes.

\section{ON DONORS AND ME FECIT IN MEDIEVAL EMBROIDERIES: THE STOLE OF SAINT NARCISSUS AND THE BANNER OF SAINT OT}

The medieval embroideries of the Stole of Saint Narcissus and the Banner of Saint Ot have attracted attention among scholars for their textual and figurative content: a pair of "me fecit" embroidered inscriptions and a donor portrait. Because of these details, the textiles have traditionally been studied from the perspective of seeking to learn who the artist or patron may have been, and if she were a woman. Thus, scholarly interest has mainly revolved around the identification of the individuals responsible for their making. By taking a different approach, this paper delves into the social and religious systems that were involved in their creation. In doing so, the goal is to better understand how matters such as collective authorship, anonymity, or the cult of saints may have influenced the forms used to express the images and text found in these textiles.

Key Words: Stole of Saint Narcissus; Banner of Saint Ot; Medieval Iberian Embroideries; Medieval Female Artists and Patrons; Cult of Saints; me fecit; Donor Portraits.

Cómo citar este artículo / Citation: Abenza Soria, Verónica Carla (2021) "En torno a donantes y me fecit en los bordados medievales: la Estola de San Narciso y el Estandarte de San Ot". En: Archivo Español de Arte, vol. 94, núm. 376, Madrid, pp. 315-334. https://doi.org/10.3989/aearte.2021.18

\footnotetext{
* Este artículo es el resultado de una investigación más extensa iniciada como parte de mi Tesis Doctoral: Ego regina: Patronazgo y promoción artística en Aragón, Navarra y Cataluña (1000-1200), Universitat Autònoma de Barcelona, 2018 (en prensa), y continuada como parte de mi beca postdoctoral Juan de la Cierva Formación (FCI2019-039199-I, financiada por MICIN/ AEI/ 10.13039/501100011033) (CSIC, CCHS-IH, Madrid), y financiada por el proyecto de investigación: "The Medieval Iberian Treasury in Context: Collections, Connections, and Representations on the Peninsula and Beyond" (RTI2018-098615-b-100, IP: Therese Martin, MICIN/ AEI/ 10.13039/501100011033/ FEDER "Una manera de hacer Europa"). Agradezco a Joan Piña Piedemonte, responsable de patrimonio del obispado de Girona, que me facilitara el estudio de la estola, así como a Rose Walker, Kirstin Kennedy y Mariam Rosser-Ower en el caso del frontal/mantel de altar del V\&A. También a Therese Martin por la revisión preliminar de este artículo, así como a los tres evaluadores ciegos por sus aportaciones y observaciones.

1 veronica.abenza@cchs.csic.es / ORCID ID: https://orcid.org/0000-0002-7845-9853
} 


\section{Introducción}

Este artículo pretende profundizar en el concepto de autoría femenina en los bordados medievales. Por ello, uno de los objetivos es dilucidar si las claves para entender cómo y por qué las mujeres codificaron su autoría a través de las inscripciones y las imágenes, se encuentran en un sistema social y de creencias bien establecido, dominado esencialmente por lo masculino y fundamentalmente espiritual. Los estudios de género y, sobre todo, las investigaciones más recientes en torno a la Edad Media han indagado a conciencia sobre ello. Hoy se otorga un rol activo a las mujeres que participaron de las dinámicas de recepción de las obras, ya sea como propietarias, consumidoras o espectadoras finales de las mismas. ${ }^{2}$ Los nombres de la Estola de San Narciso y del Estandarte de San Ot (Museu del Disseny de Barcelona, Inv. 49422) indican que fueron concebidos para integrar el ajuar de dos santos. Por ello, parece oportuno plantear la pregunta a la inversa. En concreto, cuestionarse cómo un receptor masculino habría influido en las estrategias y motivaciones de las mujeres que los crearon.

Ambos bordados son bastante bien conocidos entre los estudiosos peninsulares del románico hispánico e, incluso, han llamado la atención entre algunos historiadores extranjeros. ${ }^{3}$ Su relativa notoriedad se debe a la presencia de una inscripción que identifica su autoría femenina y que se acompaña, en el caso del estandarte, de un autorretrato, o bien, de un retrato del tipo que tradicionalmente se califica de donantes. Estas premisas han motivado diversas aproximaciones formales a las obras, así como varias acotaciones estilísticas e iconográficas que, a su vez, han permitido delimitar una horquilla cronológica para su producción entre la primera mitad del siglo XI para la estola y el primer tercio del siglo XII para el pendón. Tampoco han sido pocos los esfuerzos para localizar los talleres responsables de su manufactura, ni las conjeturas sobre su posible función.

En general, el principal interés en torno a los bordados ha gravitado alrededor del sujeto histórico al que imputar su creación. Los historiadores han dado un valor documental a la firma, ideal para reconstruir biografias, especialmente en un momento en que la documentación escrita no siempre es asequible o abundante. No obstante, salvo algunas notables excepciones, ${ }^{4}$ rara vez han sido incardinados en reflexiones más profundas sobre los procesos de creación femenina de obras de arte y de arquitectura en la Edad Media. Ello, a pesar de que los sistemas de trabajo en el ámbito de la creación textil medieval han sido ampliamente estudiados. ${ }^{5}$ También, pese a que el prestigio, reconocimiento y margen de acción que este tipo de actividad devocional y profesional otorgaba a las mujeres, están bien documentados tanto en las fuentes contemporáneas como en la historiografía especializada. ${ }^{6}$

Este estudio permitirá dibujar rutas alternativas para la lectura y definición de esa misma idea de autoría y de los recursos visuales y textuales con que era expresada, no solo a partir de estas obras, sino también gracias a la comparación con otras afines. Estas nuevas vías de investigación inciden en cuestiones como el anonimato, la creación colectiva y el contexto de recepción de las obras, en este caso, ligado al culto a los santos. Con ello se matizarán o reorientarán algunas de las interpretaciones tradicionales en torno a su aparato iconográfico y epigráfico. Lo que se busca no es contribuir a la trascendencia de algún personaje sino, en definitiva, dar algunos pespuntes a los muchos flecos todavía sin rematar en la historia de la creación artística femenina de los siglos XI y XII.

\footnotetext{
2 Martin, 2012: 1-35.

${ }^{3}$ Entre los estudios más relevantes: Folch i Torres, 1915-1920: 755-761. Martín i Ros, 1992: 54-55. Mundó, 1994: 133-162. Guardia/Mancho, 1996-1997: 1455-1479. Mariaux, 2012: 415-421. Monge, 2014: 9-15. Martin, 2016: 10-11.

${ }^{4}$ Castiñeiras, 2011: 38-39. Mariaux, 2012: 415-421. Martin, 2016: 10-11.

${ }^{5}$ Sobre este tema y abarcando un arco de estudio amplio: Coatsworth/Owen-Crocker, 2018. Aunque centrado en el papel de la mujer en la producción artesanal de tejidos de seda en París entre finales del siglo XIII y principios del siglo XIV, uno de los capítulos del libro de Sharon Farmer investiga en profundidad la especialización de las mujeres en ciertos sectores relacionados con dicha actividad, así como los circuitos migratorios que utilizan hasta instalarse en la ciudad parisina: Farmer, 2017: 74-137, esp. 106-136. Para una síntesis con la bibliografía oportuna: Rodríguez Peinado, 2020: 227-253.

${ }^{6}$ Gajewski/Seeberg, 2016: 26-50.
} 


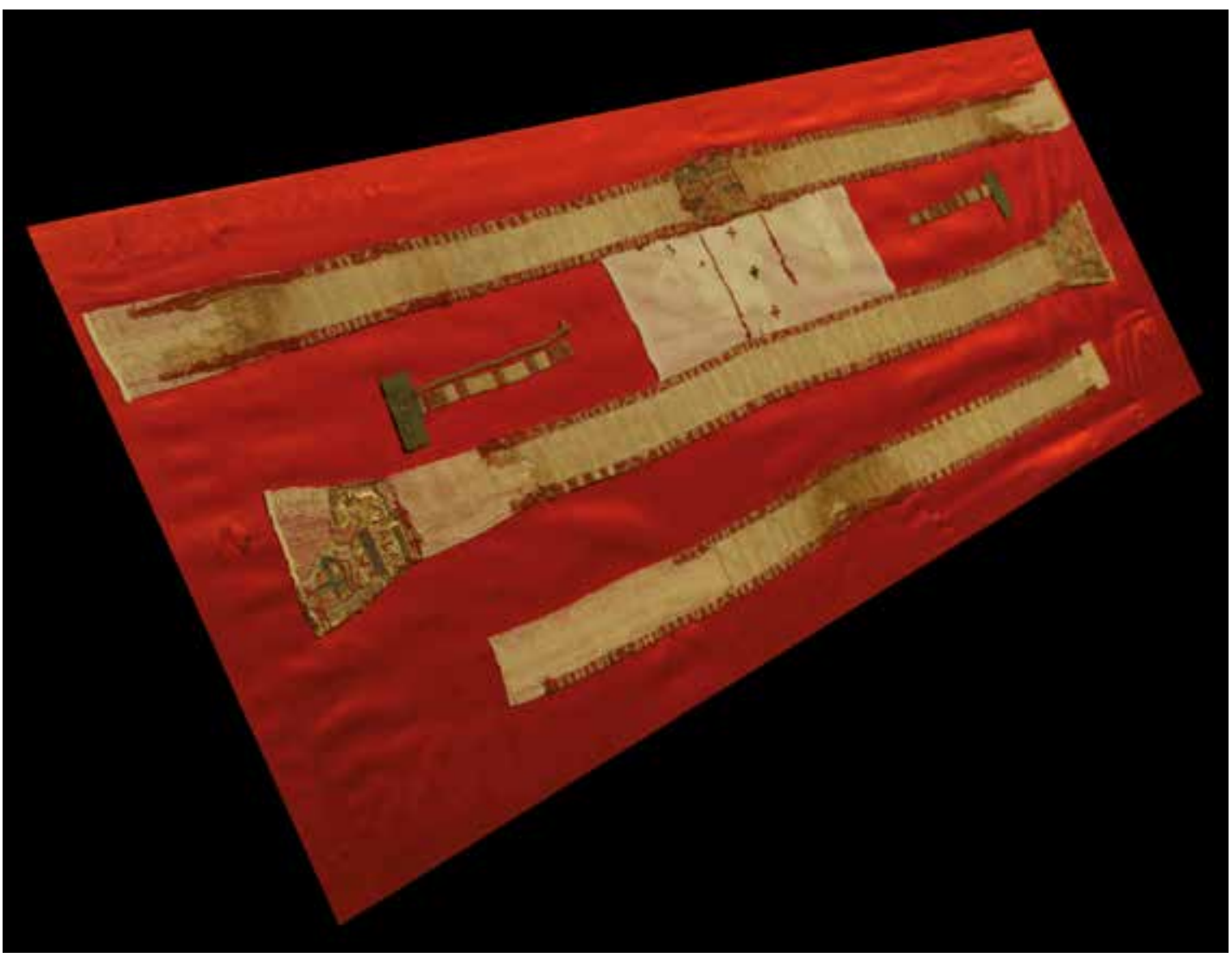

Fig. 1. Estola de San Narciso. Iglesia de Sant Feliu de Girona. Fot. Gustavo A. T. Mendoza. @ Capítulo de la Catedral de Girona.

\section{Presunciones y asunciones sobre los bordados}

La Estola de San Narciso se custodia en la basílica gerundense de Sant Feliu [fig. 1]. La historia de su redescubrimiento se remonta al 21 de agosto de 1936. Aquel día Joaquim Folch i Torres procedió a la inspección del altar y de la urna que contenía los restos de san Narciso. En aquel momento, al examinar las vestiduras que envolvían el cuerpo, se produjo el célebre hallazgo de que, por detrás de lo que se intuía como el cuello, colgaba una estola blanca con los bordes en rojo que, además, contenía inscripciones y que tenía los apéndices bordados en sedas coloreadas. ${ }^{7}$ Tras la restauración de la obra en 1955 por la Sección Textil del, por entonces, Museo de Arte de Barcelona, se emitió un primer informe elaborado gracias a las contribuciones de varios especialistas. Las aportaciones de Pilar Tomàs revelaron que se trataba de un tejido con la urdimbre de seda de color blanco y la trama de lino. Por su parte, Joan Ainaud i Rosa Maria Martín i Ros realizaron algunas puntualizaciones sobre la técnica, llamada de cartones, con punto similar al de matiz, pero más rudimentario y que la segunda calificó como prepunto de figuras. Si bien la configuración de la obra podría llevar a pensar erróneamente que se tratara de un orfré, en el momento del redescubrimiento los apéndices ya presentaban su característica forma trapezoidal. ${ }^{8}$

\footnotetext{
${ }^{7}$ Para el relato completo: Clara, 1981: 258-260.

${ }^{8}$ Sobre todas estas cuestiones relativas a la restauración de 1955 y a las observaciones técnicas de los distintos autores condensadas en el informe: Tomàs, 1956: s.p. Agradezco a los responsables del Archivo del Instituto del Patrimonio Cultural de España la información sobre el informe de la restauración de la estola llevada a cabo por el IPCE y concluida en agosto de 2021 y que se elaborará este próximo mes de septiembre. Dicho informe con las conclusiones extraídas a raíz
} 
Aunque el relato de Folch i Torres no da lugar a duda sobre la relación de dicha estola con el santo, cabe recordar que los huesos de san Narciso habían sido objeto con los siglos de varias profanaciones, algunas de las cuales documentadas ya en 1285. Los restos, además, se instalaron en varios sepulcros hasta depositarse definitivamente en la urna-sarcófago no solo con la dicha estola sino con un juego de indumentaria presbiteral casi completo. ${ }^{9}$

En cuanto a la mención más antigua de la obra a finales del siglo XI, se conoce que Sighard (1084-1099), abad del monasterio de St. Ulrich und Afra de Augsburg, envió a Girona una delegación encargada de compilar algunas reliquias de san Narciso al que se debía supuestamente la conversión de la titular de su abadía, santa Afra. La gestión la afrontó personalmente el obispo gerundense Berenguer Guifredo (1050-1093) quien, en 1087, remitió de vuelta una carta detallando el resultado de la empresa. ${ }^{10}$ En la misiva, el prelado explicaba que no podía expedir a Augsburg nada que tuviera relación con el cuerpo de san Narciso del que decía se había conservado milagrosamente incorrupto. En compensación, envió algunas reliquias del tipo brandea, esto es, de contacto directo con el cuerpo del santo, en concreto, "stola, cum quibus conditus est in sepulcro", es decir, una estola con la que estaba enterrado en su tumba-sarcófago. Parece plausible, por tanto, que en 1087 Berenguer Guifredo extrajera algunos recortes de la Estola de San Narciso y que esa fecha constituya, en consecuencia, un terminus ante quem para su confección. Esta suposición, en cualquier caso, se reforzaría, - aunque sin poder demostrarse totalmente-, a razón del estado en que en 1936 fue recuperada la estola. Se hallaba dividida en tres partes de anchura análoga y de largura desigual, con los apéndices del tercer fragmento bordados y, según pudo examinar Rosa Maria Martín i Ros, ambos cortados. ${ }^{11}$ Siendo así, no se puede descartar que el obispo de Girona hubiera extraído algunos de los recortes expedidos a Augsburg de los propios apéndices.

La estola fue decorada con una larga inscripción que recorre el centro y cada uno de los bordes, y cuyo contenido, según ha podido preservarse, reza [fig. 2]:

(in) (nOmi)NE DOMIN(u)S NOSTRI HIESU XP(ist)i PATREM CUM PROL(em) // EORUMQUE SP(iritu)M ALMUM (utri)USQUE TRINUM DEITATIS CREDIMUS UNNUM

BENEDICAD NOS DEUS PATER CUSTODIAT \{nos hiesus\} (x)P(istu)S INLUMINET NOS SPIRITUS SANT(us) () VITE NOSTRE CONFIRMED NOS UIRTUS XPI(st)I // INDULGEAT NOBIS DOMINUS (u)NIVER(salis)\{a delicta nostra\} ATIUTORIUM + NOSTRUM + IN NOMINE + DOMINI + QUI M()

() XP(istu)S UINCIT XP(istu)S REGNAT XP(istu)S IMPERAT EXAUDI XP(ist)E TU ILL(um) \{adjuua\} (s) ALUS ET UITA $\mathrm{s}(\mathrm{an}) \mathrm{C}(\mathrm{t})$ A MARIA TU ILLUM ADJUUA // (re)DEMTOR NOSTER REDEMCIO TUA NE (pere)AT IN NOBIS (vid)EAS AMICE MARIA ME FECIT QUI ISTA STOLA PORTAUERIT SUPER SE ORAD PRO ME SI DEUM ABEAD A $\{\text { tiutorem }\}^{12}$

(En el nombre de Nuestro Señor Jesucristo, el Padre, con su Hijo y el Espíritu Santo, uno y tri, cada deidad trinitaria creemos una. Bendícenos Dios Padre, custódianos Jesucristo, ilumínanos Espíritu Santo. Confirma nuestras vidas virtuoso Cristo, perdónanos Señor Universal nuestros delitos. Auxilio nuestro en el nombre del Señor quien me (...) Cristo vence, Cristo reina, Cristo impera escucha Cristo a tu auxiliante, salud y vida Santa María, tu auxiliante. Redentor nuestro, tu redención no perece en nosotros. Recuerda amigo María me hizo. Quien esta estola lleve sobre de sí, rezad por mi alma para tener la ayuda de Dios.)

de la restauración indudablemente aportará nuevos e interesantes datos relativos a estas cuestiones. También agradezco a Joan Piña, responsable de Patrimonio de la Diócesis de Girona y director del Museu del Tresor de la Catedral de Girona por haberme facilitado las fotografías de la estola realizadas por Gustavo A. T. Mendoza con posterioridad a la finalización de la restauración y que se publicarán en este artículo.

9 Martín i Ros, 1991: 149.

${ }_{10}$ Para la edición crítica de la carta y una síntesis de su contenido: Mundó, 1974: 101-103; 1995: 9-10.

${ }^{11}$ Para las medidas: Martín i Ros, 1991: 145.

12 Mundó, 1994: 144. Se sigue el orden de transcripción según determina la lógica ordenación de los fragmentos tal y como debían formar la estola originalmente, a fin de concretar una secuencia de lectura coherente de la inscripción. Los () se utilizan para las omisiones y los \{\} para las omisiones conjeturadas por el autor. 


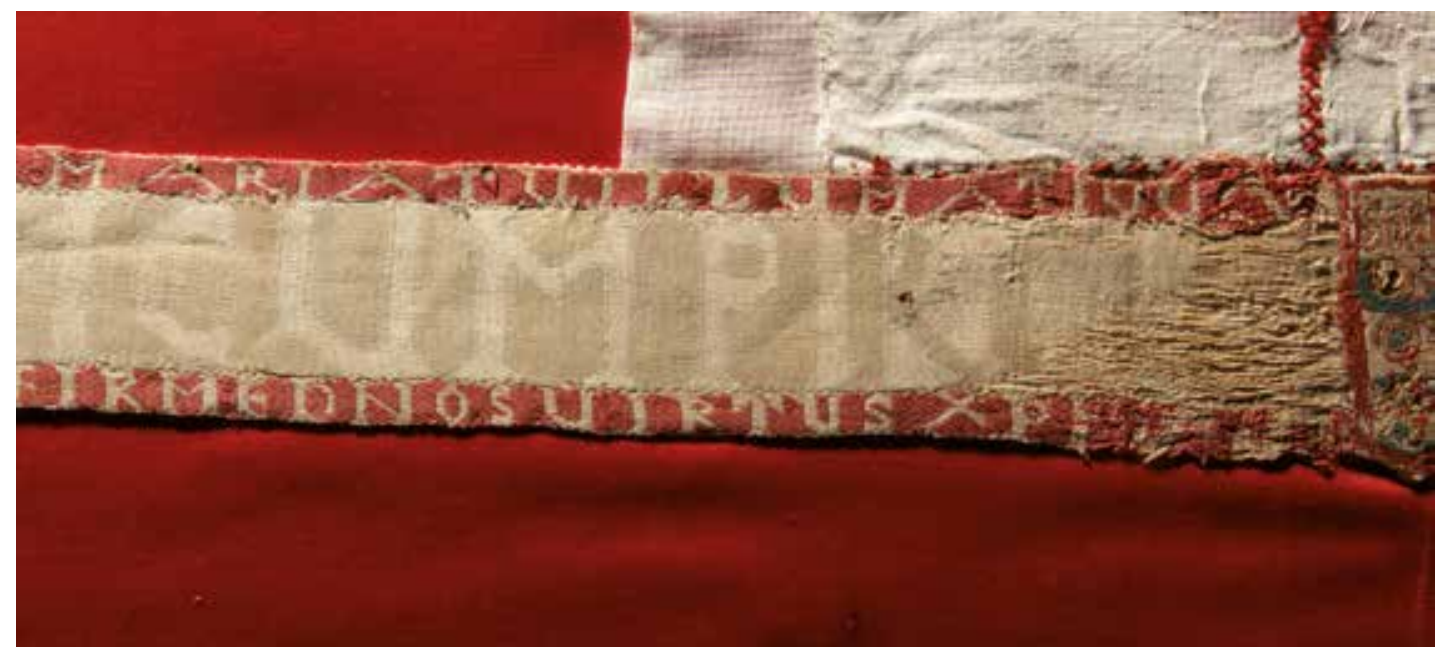

Fig. 2. Estola de San Narciso. Detalle de la inscripción. Fot. Gustavo A. T. Mendoza. C Capítulo de la Catedral de Girona.

Las imágenes bordadas en los apéndices de la estola se concibieron como las miniaturas que en un manuscrito acompañan al texto ilustrándolo, es decir, como un ejercicio de síntesis visual de los

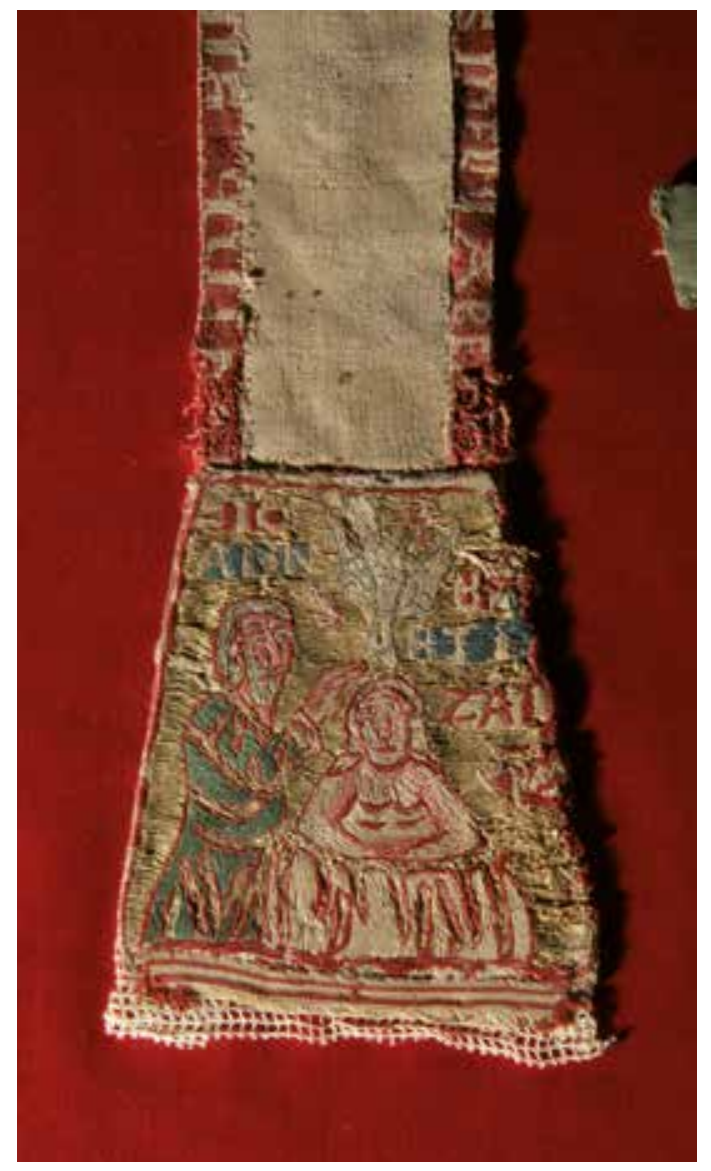

Fig. 3. Estola de San Narciso. Detalle del bordado con la representación del Bautismo de Cristo. Fot. Gustavo A. T. Mendoza. (C) Capítulo de la Catedral de Girona. textos. La escena del Bautismo de Cristo ilustra, por ejemplo, la loa al dogma trinitario de uno de los versos [fig. 3]. La figuración de la Virgen en el bordado central se pensó, en cambio, para evocar la capacidad mediadora de María. De hecho, traduce la glosa de uno de los epígrafes que la caracteriza como auxiliante de Cristo en su tarea redentora [fig. 4]. La representación del tercer bordado está centrada en el martirio de san Lorenzo [fig. 5].

De la rica epigrafía de la estola, el fragmento que más interés ha suscitado es aquel que condensa su autoría: "(vid)EAS AMICE MARIA ME FECIT" (recuerda amigo María me hizo). La teoría que, generalmente, había tenido mejor acogida fue enunciada por Anscari Mundó, quien identificó a la "María" que menciona el epígrafe con una abadesa homónima del siglo $\mathrm{X}$ del convento de Santa Maria de les Puel·les de Girona. ${ }^{13}$ Sin poder concordar con esa datación tan alta, en lo sucesivo, otros autores se han inclinado por vincular el nombre con una monja con un horizonte vital posterior. Se ha postulado que la religiosa procediera de aquel mismo convento o, incluso, del cercano monasterio de Sant Daniel de Girona, a cuya comunidad se atribuye la confección de otros célebres bordados, ${ }^{14}$ creyéndola ya la artista,,${ }^{15}$

\footnotetext{
13 Mundó, 1994: 143-144.

14 Castiñeiras, 2011: 38.

${ }^{15}$ Castiñeiras, 2011: 38.
} 


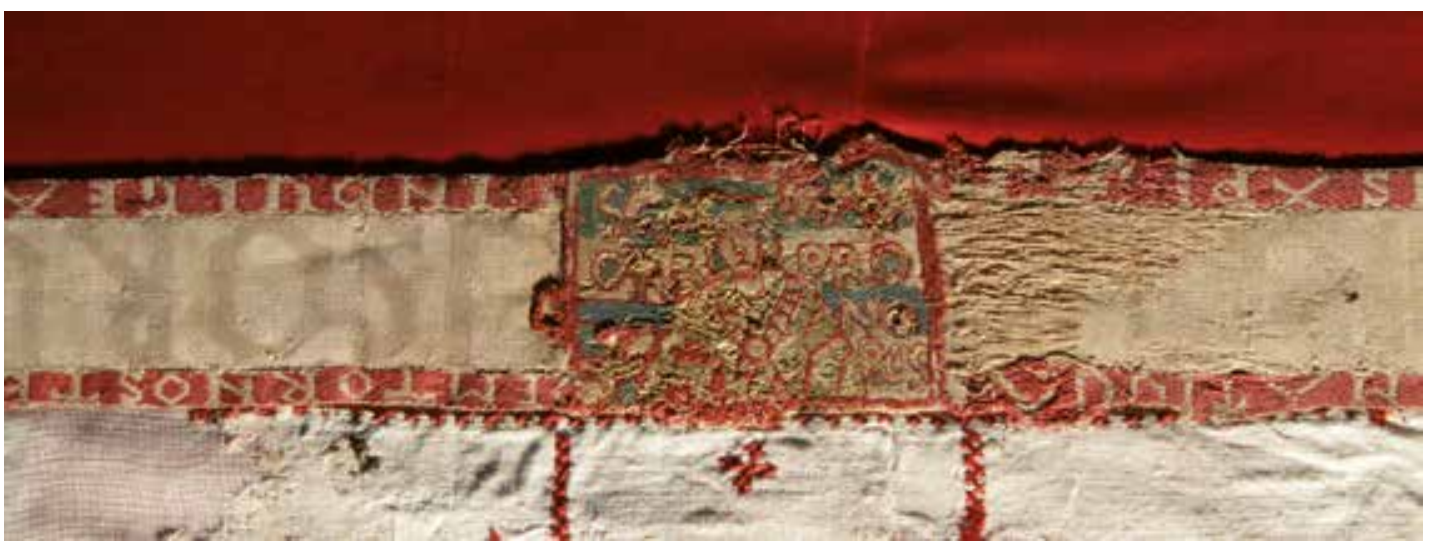

Fig. 4. Estola de San Narciso. Detalle del bordado con la representación de la Virgen. Fot. Gustavo A. T. Mendoza. C Capítulo de la Catedral de Girona.

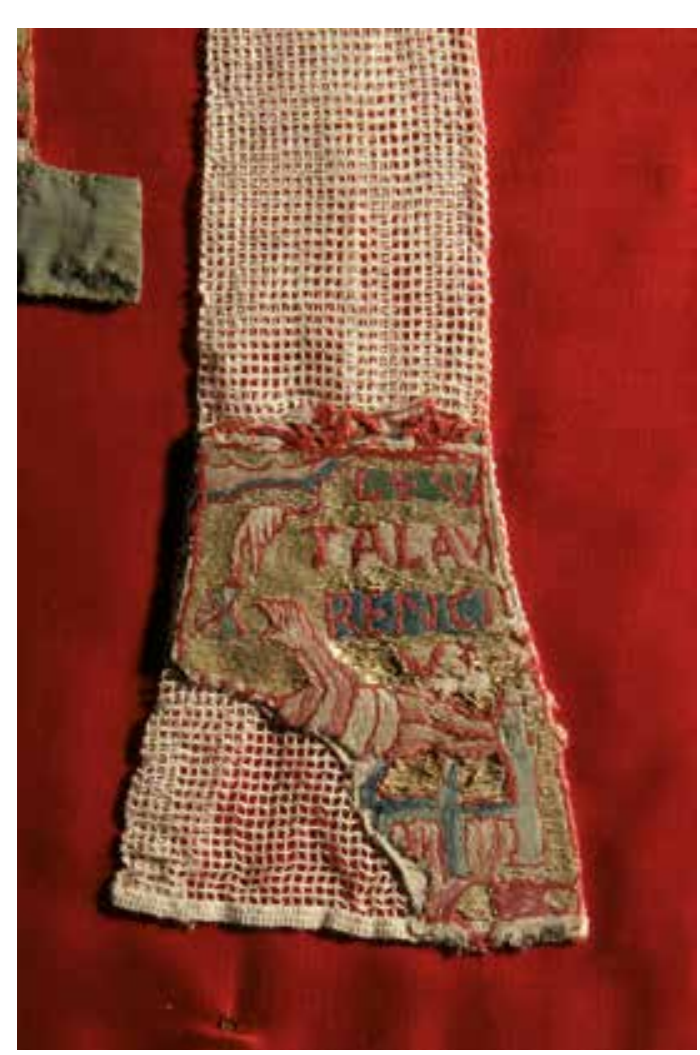

Fig. 5. Estola de San Narciso. Detalle del bordado con la representación del Martirio de San Lorenzo. Fot. Gustavo A. T. Mendoza. (C) Capítulo de la Catedral de Girona. ya la promotora. ${ }^{16}$ Siendo factible, como observó Pere de Palol, ${ }^{17}$ que la epigrafía de la estola se inscriba en los años centrales del siglo XI, Manuel Gómez Moreno y Rosa Maria Martín i Ros relacionaron la figuración de los bordados con la estética románica, colocándola entre los siglos XI y XII. ${ }^{18}$ Sin embargo, la aproximación estilística más verosímil es la que plantea Manuel Castiñeiras, emparentándola con algunos rasgos de la miniatura rivipullense de mediados del siglo XI y las miniaturas de las Homilías de Beda de Sant Feliu de Girona (Museu Diocesà de Girona, Inv. 44). ${ }^{19}$

Joaquim Folch i Torres también fue responsable del hallazgo moderno del Estandarte de San Ot [fig. 6]. Su redescubrimiento derivó de un viaje que, a principios del siglo XX, realizó a la Seu d'Urgell. Gracias a su descripción se conoce que la arqueta que contenía el pendón estaba custodiada al interior de la catedral urgelitana, en concreto, en uno de los nichos abiertos en dos plafones laterales del altar parroquial. ${ }^{20}$ Casi inmediatamente después la obra se puso en relación con otro bordado (V\&A, Inv. 13871904) [fig. 7]. Esta obra se designa generalmente como un frontal, si bien, no presenta ningún indicio físico de haber sido colgado, pudiendo tratarse de un mantel de altar. La razón para establecer la relación entre las dos obras se halla en su procedencia desde la propia Seu d'Urgell,

\footnotetext{
16 Guardia/Mancho, 1996-1997: 1458-1459, 1463.

${ }^{17}$ Así mismo sería igualmente puntualizado por Á. Fábregas: Tomàs, 1965: s.p.

18 Tomàs, 1965, s.p. Cfra. Martín i Ros, 1991: 149.

${ }^{19}$ Castiñeiras, 2011: 38.

${ }^{20}$ Folch i Torres, 1915-1920: 755.
} 


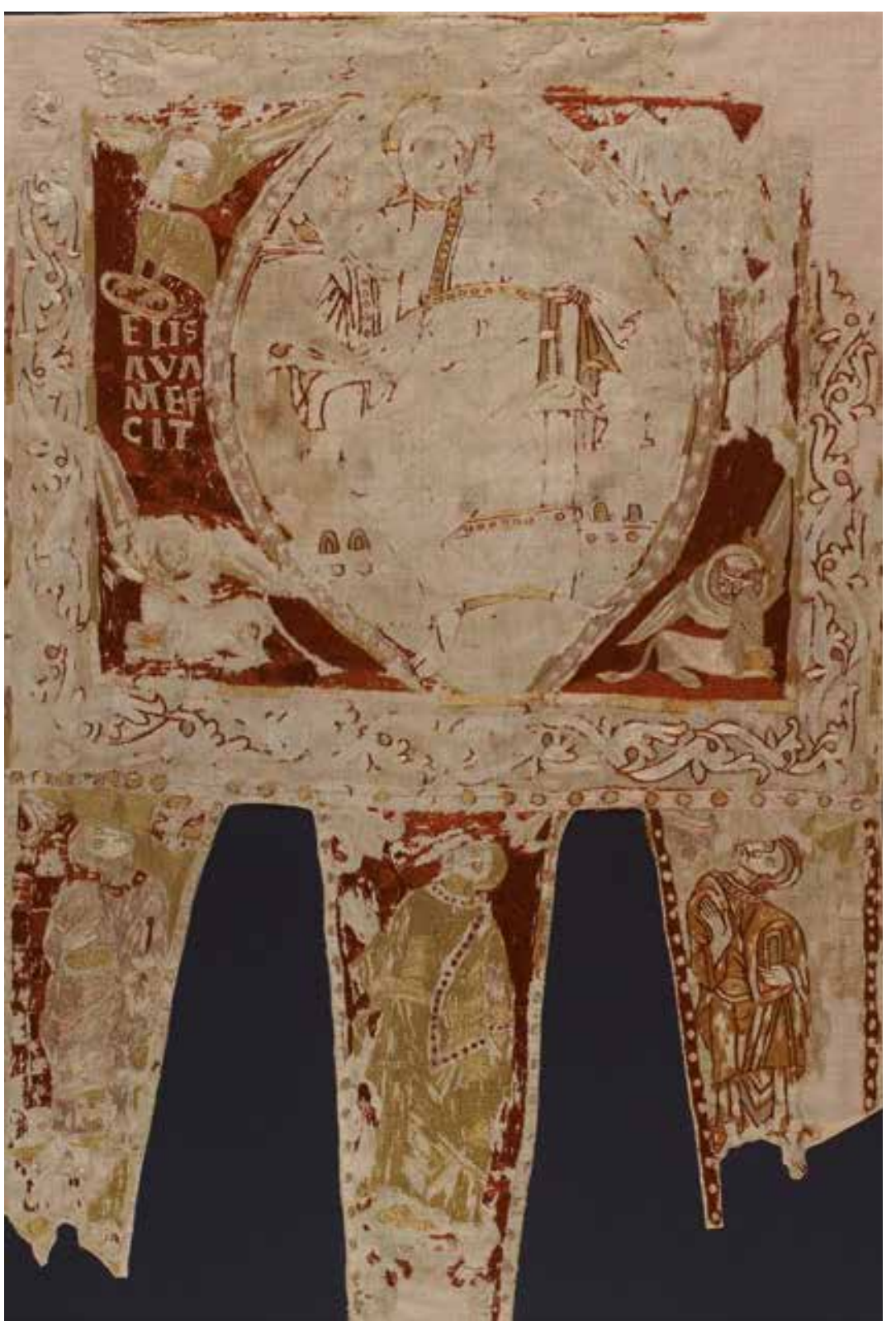

Fig. 6. Estandarte de San Ot. Museu del Disseny de Barcelona. MADB 49422. (C) Autora.

sobradamente acreditada gracias al intercambio epistolar entre Josep Gudiol i Ricart y Donald King. ${ }^{21}$

El titular del altar donde fue encontrado el estandarte era san Ot, patrón de la ciudad y obispo de Urgell entre 1095 y 1122. En la descripción de Folch i Torres se consigna como altar parroquial pues, desde antiguo, el altar de san Ot fue reservado, igualmente, a la parroquia. ${ }^{22}$ En 1535, el capítulo urgelitano procedió a la reordenación de las capillas de la catedral lo que supuso el traslado de dicho altar. Se decidió, en concreto, que pasara "a aquell en què hi havia el de sant Ermengol" (a aquel en el que estaba el de san Ermengol). En todo caso, gracias a una asignación de beneficios

${ }^{21}$ Gudiol i Ricart, et al., 1955: 42. King, 1970: 55-56, 63.

${ }^{22}$ Batlle, 1980: 382, 385, 404, 408-409, 413-414. 


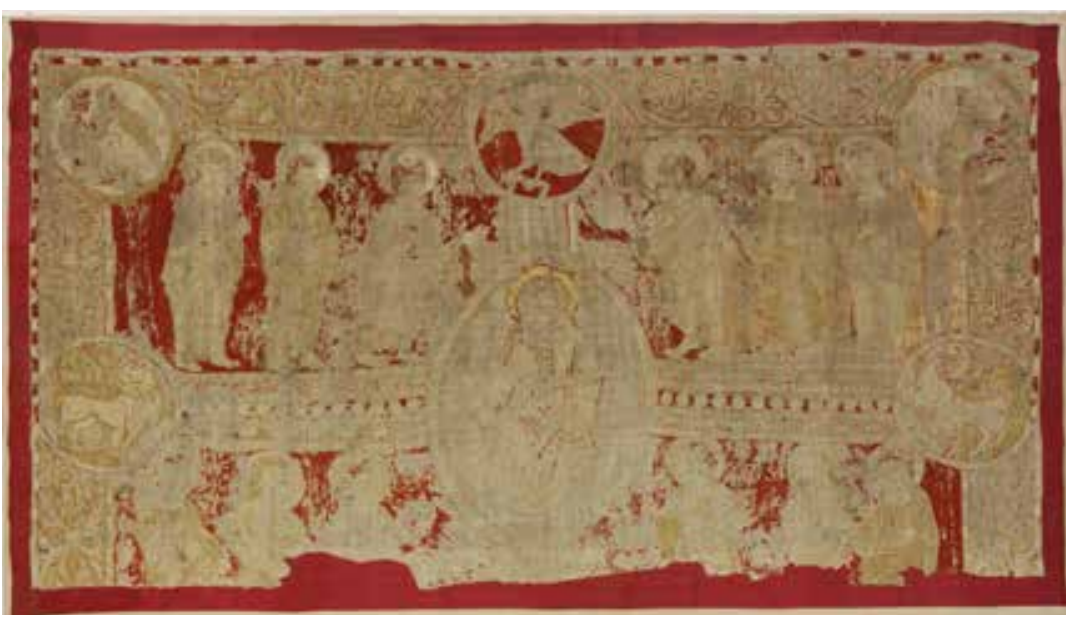

Fig. 7. Frontal/mantel de altar. Victoria and Albert Museum. V\&A 1387-1904. (C) Victoria and Albert Museum. Con permiso.

de $1557,{ }^{23}$ sabemos que la situación original del altar de san Ot coincidía con el primer tramo de la nave de la Epístola.

San Ot fallece el 30 de junio de 1122, recibiendo pronto entierro en la catedral de la Seu d'Urgell, en un sepulcro episcopal hace tiempo desaparecido. ${ }^{24}$ No obstante, el santo fue exhumado en fecha temprana para pasar su cuerpo al altar dónde se le veneraba. En 1556 se abrió el arca de madera que contenía sus restos sobreviniendo el hallazgo dentro de ella de "terra treta del seu sepulcre" (tierra extraída de su sepulcro). ${ }^{25}$ Esta tierra pertenecía, por tanto, al primer sepulcro, del que desafortunadamente se conoce solamente el epitafio. Dicha dedicatoria hace presente la ascendencia noble del santo, en concreto, de la dinastía condal pallarsense, nacido del matrimonio entre Artal I, de Pallars Sobirà (1049-1081) y Lucía de la Marca (c. 1030-1090). ${ }^{26}$

Las cuestiones relativas a la técnica y materiales de los bordados urgelitanos han servido para sustanciar su producción en un marco temporal más o menos similar y en un mismo taller, ya fuera del entorno catedralicio o ubicado en el cenobio femenino urgelitano de Santa Cecilia de Elins. ${ }^{27}$ De hecho, en ambos son recurrentes tanto la técnica, conocida como "pintura a la aguja" (opus pictus), como el empleo de los mismos materiales con hilos de seda policroma de poca torsión. ${ }^{28}$ El estandarte está formado por varias piezas. La mayor consiste en una sección rectangular de la que penden tres gallardetes de formato trapezoidal. El dibujo permite plantear la relación más cercana, -en términos de estilo-, con los frontales sobre tabla de Ix y de los Apóstoles (MNAC, Inv. 015802 y 015803), obras ambas atribuidas al llamado taller de la Seu d'Urgell hacia 11201130, lo que constituye el dato cronológico más preciso. En ambos la iconografía se centra en la representación de la Maiestas Domini flanqueada por el Tetramorfo, y custodiada, además, por un apostolado y por los ríos del Paraíso en el caso del frontal/mantel de altar.

En cuanto al pendón, la atención se ha centrado en las figuras que acogen los gallardetes, con las manos alzadas en gesto orante. Su tipificación como mujeres deriva de la asociación de sus tocados con la llamada guimpa. Se trata de una prenda vinculada al uso monástico y, en particular, una especie de cofia que durante la Edad Media vestían las religiosas. Este detalle ha motivado, incluso, la interpretación de los tres personajes como monjas. Casi por analogía, se han ofrecido lecturas generalizadas para las tres figuras, - representadas una para cada flámula-, en lo que

${ }^{23}$ Pujol i Tubau, 1922: 331-352; 1927: 1-29.

${ }^{24}$ Villanueva, 1803-1852 (2001), XI: 496, Ap. VIII.

25 Folch i Torres, 1915-1920: 755-756.

26 Villanueva, 1803-1852 (2001), XI: 496, Ap. VIII.

${ }_{27}^{27}$ Martín i Ros, 1997: 426. Monge, 2014: 15-25. Frente a esta opinión, casi unánime, solo X. Barral considera el frontal/mantel de altar una obra de más avanzado el siglo XII: Barral, 2009: 275. Sobre las cuestiones técnicas: Martín i Ros, 1992: 54; 1997: 425-426.

${ }^{28}$ Martín i Ros, 1992: 54. 


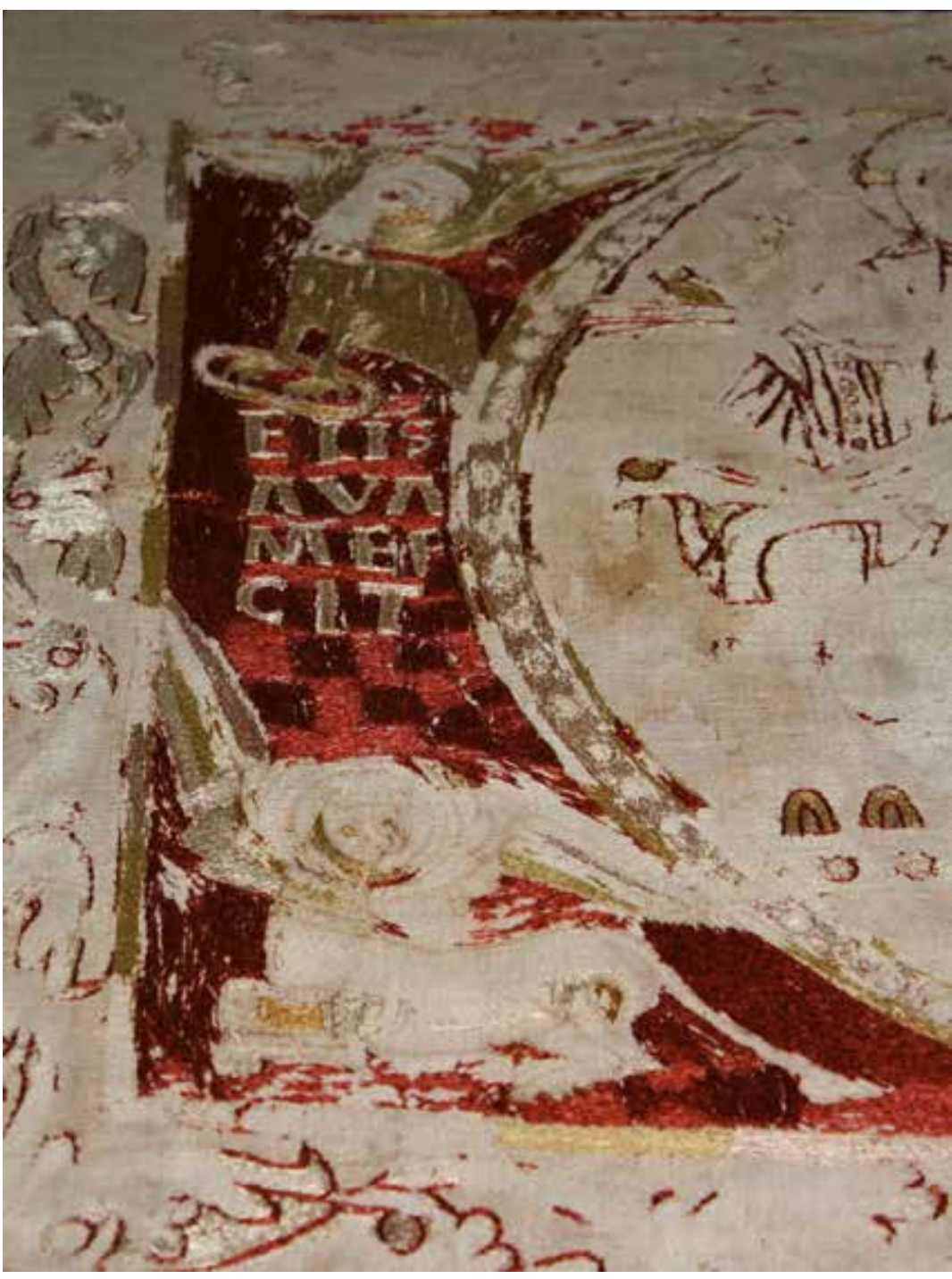

Fig. 8. Estandarte de San Ot. Detalle de la inscripción. (C) Autora.

respecta a su indumentaria y atributos. Su representación y la presencia de una inscripción en el rectángulo superior del pendón que reza "ELIS/AVA ME F(e)/CIT" (Elisava me hizo) [fig. 8], ha justificado, como un correlato, la identificación de la titular de la firma con alguno de los personajes retratados en los gallardetes. Esto ha suscitado el debate, con opiniones encontradas, acerca de la asociación de dicha "Isabel" bien con la promotora, ${ }^{29}$ bien con la artífice de la obra. ${ }^{30}$ No obstante, el horizonte vital de las candidatas aparentemente más idóneas, Isabel de Urgell (c. 1048-1085), primera esposa del rey de Aragón Sancho Ramírez, y las hija (1092-1095) y hermana (1102-1154), respectivamente, de los condes urgelitanos Ermengol V y Ermengol VI, fue muy distante, - salvo en el caso de la tercera-, de la cronología más plausible para la confección de los bordados hacia 1120-1130. Por ello, a continuación, se propondrá una interpretación conjunta y diversa de la inscripción y de las imágenes de los gallardetes.

${ }^{29}$ Martín i Ros, 1992: 54. Guardia/Mancho, 1996-1997: 1472-1474.

${ }^{30}$ Como aún se mantiene en los estudios más recientes: Castiñeiras, 2011: 38-39; 2014: 29. En algún caso también se ha dejado abierta la cuestión: Mariaux, 2012: 421. Monge, 2014: 19. Martin, 2016: 9. 


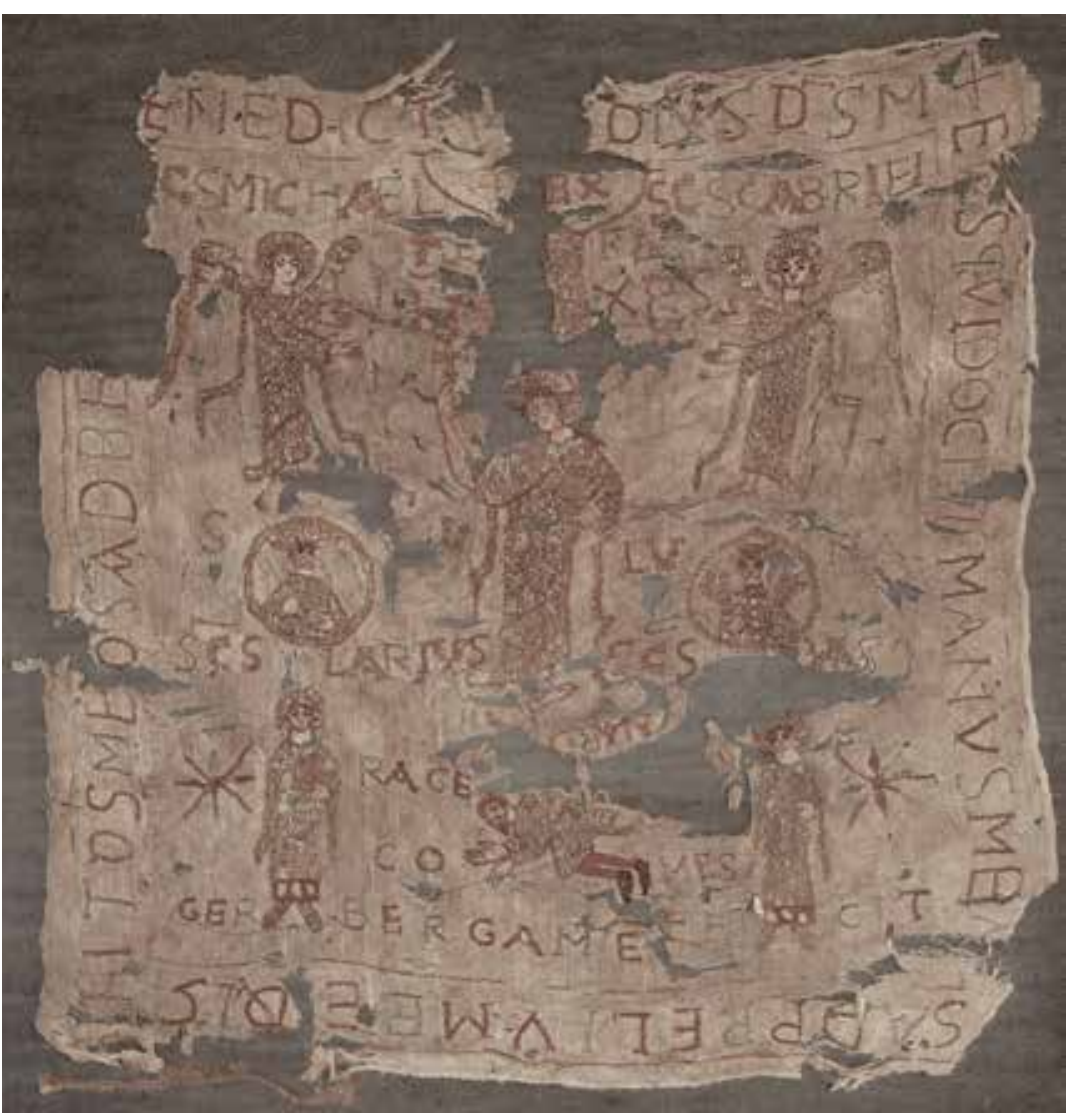

Fig. 9. Kriegsfahne.

Köln, Köln Dom,

Domschatzkammer, L1.

(c) Wikipedia Commons license.

\section{Cuestiones controvertidas sobre la interpretación de las inscripciones con me fecit y los retratos de donantes con relación a los bordados}

Los epígrafes medievales que incluían uno o varios nombres seguidos de una forma del verbo facere y una mención a la obra de arte o de arquitectura, referían todo tipo de acción de creación artística. Así, podían aludir, sin esclarecerlo, tanto al trabajo manual del artista como al apoyo económico del promotor o, incluso, al impulso intelectual del ideólogo del discurso decorativo. ${ }^{31}$ Por ello, para el historiador contemporáneo, interpretar este tipo de inscripciones constituye un problema cuando, como en el caso de la estola y del pendón, no se dispone de documentos gráficos o escritos adicionales. Recientemente, Émilie Mineo ha llegado a la conclusión de que a partir de principios del siglo XII comenzará a imponerse la tendencia a reservar a los artistas la forma verbal me fecit. ${ }^{32}$ No obstante, ejemplos más tardíos del propio ámbito textil revelan cómo esta ambivalencia es, todavía, difícil de resolver. Así se demuestra con una banda confeccionada en el siglo XIV como frente de altar por Johanna Beverly y recorrida por la inscripción "DOM[i]NA IOHANNA BEVERLAI MONACA ME FECIT" (La monja Johanna Beverly me hizo) (V\&A, Inv. T.70-19023), pues según la escueta información del epígrafe dicha religiosa bien pudo tejerla, promoverla o ambas.

El llamado Estandarte de Gerberga, fechado en el siglo X y decorado con el epígrafe "GER/ BERGA ME FE/CIT" (Gerberga me hizo) [fig. 9], ilustra cómo la interpretación de este tipo de inscripciones ambivalentes resulta más factible no solo cuando van acompañadas de un retrato, sino también cuando imágenes y epigrafía permiten reconstruir un contexto bien documentado. En su

${ }^{31}$ Una reflexión sistemática de esta cuestión en: Favreau, 1992: 681-727; 1999: 37-59.

32 Mineo, 2018: pp. 231-242. 

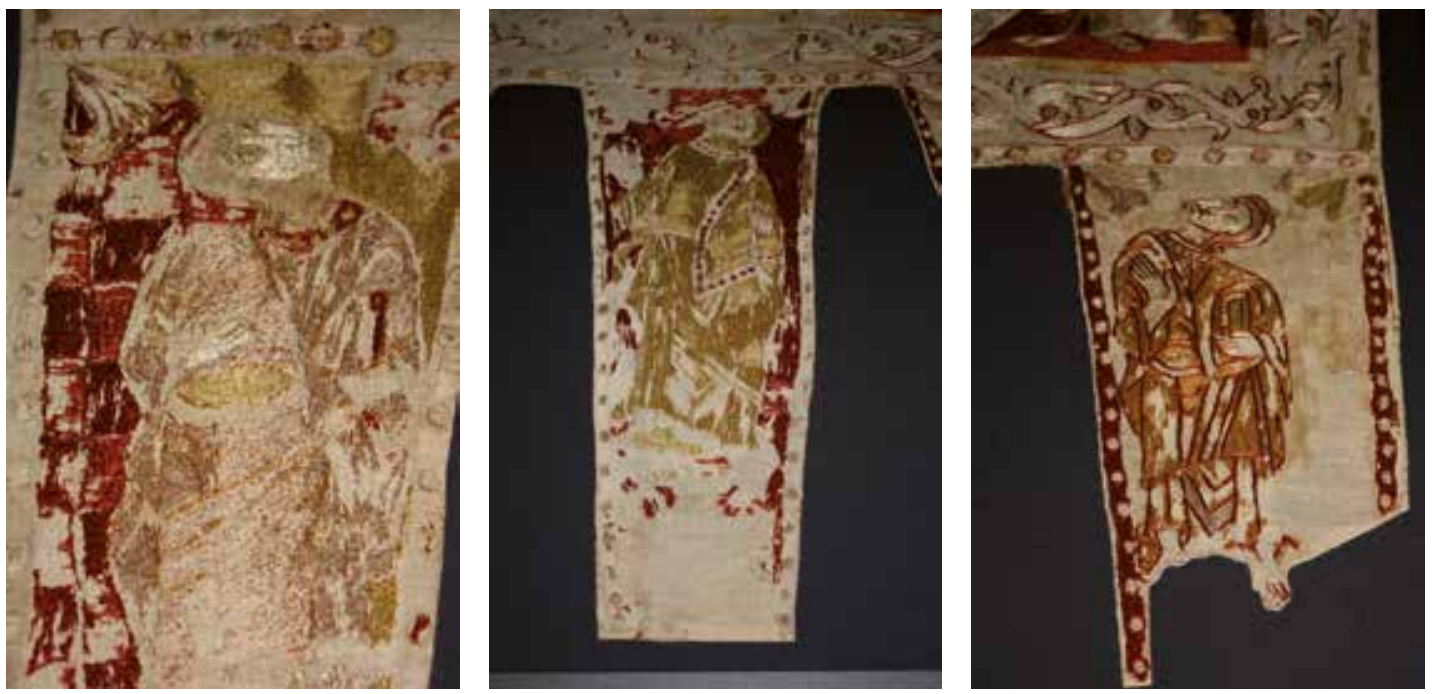

Figs. 10-12. Estandarte de San Ot. Detalles de los gallardete. (C) Autora.

caso, ciertos recursos como la firma, la procedencia de la obra de la catedral de Colonia, la documentación escrita conservada y la representación a los pies de la Maiestas Domini de un personaje postrado identificado por el titulus como el conde Reginardus, han permitido hilvanar la creación del pendón por Gerberga (c. 913-968), hermana del emperador Otón I († 973) y del arzobispo Bruno de Colonia $(\dagger 965) .{ }^{33}$

Por tanto, cabría preguntarse si, dada la importancia de interpretar conjuntamente epígrafes y retratos, la iconografía del Estandarte de San Ot podría arrojar cierta luz sobre su enigmática firma. Una lectura a simple vista de los retratos de las flámulas, al llevar las cabezas veladas, permite aventurar que se trate de mujeres. Tras una observación más atenta, sin embargo, emergen varios detalles que permiten matizar el género y el estatus de las figuras. La indumentaria de la primera, con túnica, manto y una cofia que le cubre ininterrumpidamente la cabeza y el cuello, bien puede caracterizarse como la de una religiosa [fig. 10]. Sutilmente distintas son, en cambio, las vestimentas de sus compañeras. En la central, aunque el personaje se cubre la testa, el tocado no alcanza la nuca. De hecho, es muy similar a la mitra que luce san Ramón en el sepulcro homónimo de Roda de Isábena. Además, aunque se representa igualmente con una túnica, la pieza de ropa que viste justo por encima se asemeja en su forma más a la de una capa pluvial o casulla que a la de un manto. Este tipo de prenda propia del ámbito clerical está en consonancia además con otro de sus atributos, el llamado cingulum, un cinturón que, a través del contenido del evangelio de san Juan, se asociaba al uso sacerdotal. Su posible identificación, por tanto, con un clérigo, quizá con el propio san Ot, se hace posible, más si consideramos el objeto que sostiene entre las manos. Parece sujetar algún tipo de instrumento para la liturgia tal que, por su forma redondeada, un incensario o un aspersor [fig. 11]. Por su parte, aunque la tercera figura va ataviada con túnica y manto, el tocado deja al descubierto una buena porción de sus cabellos, pudiendo lucir no una guimpa, sino un velo y, con ello, anunciar su pertenencia al ámbito laico [fig. 12].

De haberse configurado las imágenes de los gallardetes como un autorretrato de artista quizá cabría esperar que lucieran alguno de los útiles de su desempeño como bordadoras o tejedoras, tal que un huso o una aguja. De hecho, en autorretratos femeninos de fechas más o menos cercanas, la artista suele representarse en relación con algún detalle que hace referencia a su oficio y a la obra ejecutada. Este es el caso, por ejemplo, de la miniatura de finales del siglo XII que representa a la miniaturista Guda del Homiliario de Frankfurt (Frankfurt am Main, Universitätsbibliothek

\footnotetext{
${ }^{33}$ Mariaux, 2012: 398-399.
} 


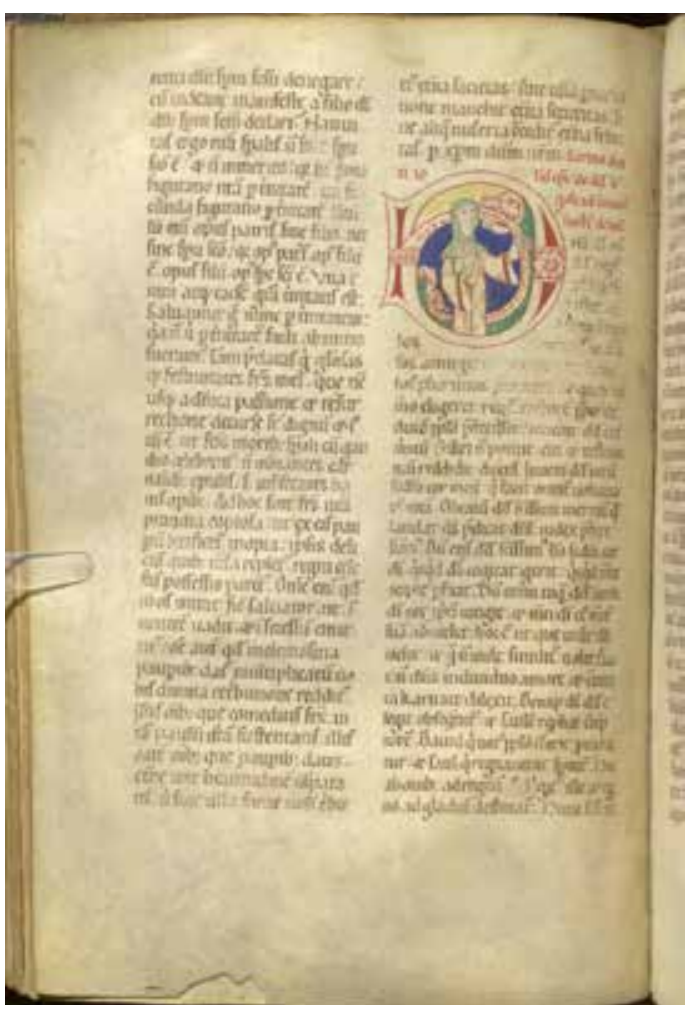

Fig. 13. Homiliario de Frankfurt. Frankfurt am Main, Universitätsbibliothek Johann Christian Senckenberg, Ms. Barth, 42, f. 110v. (O) oberlin.edu

Johann Christian Senckenberg, Ms. Barth, 42, f. $110 \mathrm{v}$.) ${ }^{34} \mathrm{y}$ dónde la artista aparece abrazando una de las iniciales iluminadas del manuscrito [fig. 13]. Es más probable, en consecuencia, que los retratos de las flámulas laterales se concibieran como un retrato de donantes.

Por un lado, el gesto suplicante y de adoración de las manos alzadas en dirección a la Maiestas Domini se hace reminiscente de otros tantos retratos femeninos semejantes y de cronología afín como la representación a los pies del Crucificado de la reina Gisela en el Crucifijo de la reina Gisela de Hungría (a. 1065). Por otro, la combinación entre la firma y esta iconografía centrada en representar a los donantes junto al santo patrón evoca un modelo de representación de la autoría que se perpetua en obras textiles de cronología más tardía. En particular, recuerda la composición de dos manteles de altar confeccionados en el siglo XIV para el convento femenino de Altenberg. Ambas obras aluden explícitamente tanto a los promotores como a sus artífices. En el mantel de altar conservado en The Metropolitan Museum of Art (MMA, Inv. 29.87) una de las inscripciones incorpora tres nombres femeninos: "SOPHIA. HADEWIGS. LUCARDIS. FACER(un)T ME/ IHESU. BENIGNE. OPUS. NOSTR(u)M. SIT (tibi) ACCETABILE" (Sofia, Hadewigs, Lucardis me hicieron. Acepta Jesús nuestra buena obra) [fig. 14]. El uso del verbo facere y la falta de cualquier referencia a la ejecución material de la obra a priori invitan a pensar en las tres mujeres tanto como posibles donantes o artistas. Sin embargo, la representación en el mismo mantel de altar de un monje arrodillado e identificado gracias a su escudo de armas como Henricus de Cronenberg, ha permitido postular a este personaje como el responsable del encargo.$^{35}$ Con todo, como ha señalado Stefanie Seeberg, los manteles de Altenberg incluyen también la representación de varias monjas, de las cuales solo se identifica a una religiosa llamada Gisela. Las otras se figuran anónimamente con la intención de aludir conjuntamente a toda la comunidad monástica. La actitud de las religiosas es, además, similar a la de las mujeres del Estandarte de San Ot, con sus manos elevadas y dirigidas en gesto de veneración hacia Dios y un grupo de santos. El anonimato contribuye así a visibilizar cómo el convento participa colectivamente de la acción de creación. Con este tipo de lenguaje visual se subraya, además, la naturaleza piadosa tanto de la donación como de la ejecución material del mantel, entendidas como un intercambio del que se espera una recompensa en forma de salvación. Seguramente, las claves para entender las diferencias con respecto a los retratos anónimos del estandarte se hallen en algunos de los atributos que sostienen las figuras de los gallardetes.

Los atributos de las mujeres representadas en las flámulas laterales se han identificado tradicionalmente con el Libro de los Evangelios. No obstante, la cartilla que ciñe la mujer de la izquierda, por su terminación en voluta, es similar al remate curvo de algunas filacterias y recuerda más a la forma de un rollo. El volumen de la mujer del lateral opuesto, en cambio, por la rica decoración de los márgenes del frontispicio, es evocativo de las formas asociadas a un manuscrito con en-

\footnotetext{
${ }^{34}$ Mariaux, 2012: 399-409, 413-415.

${ }^{35}$ Sobre estos tejidos de Altenberg: Seeberg, 2012: 357-367; 2014: 175-256.
} 


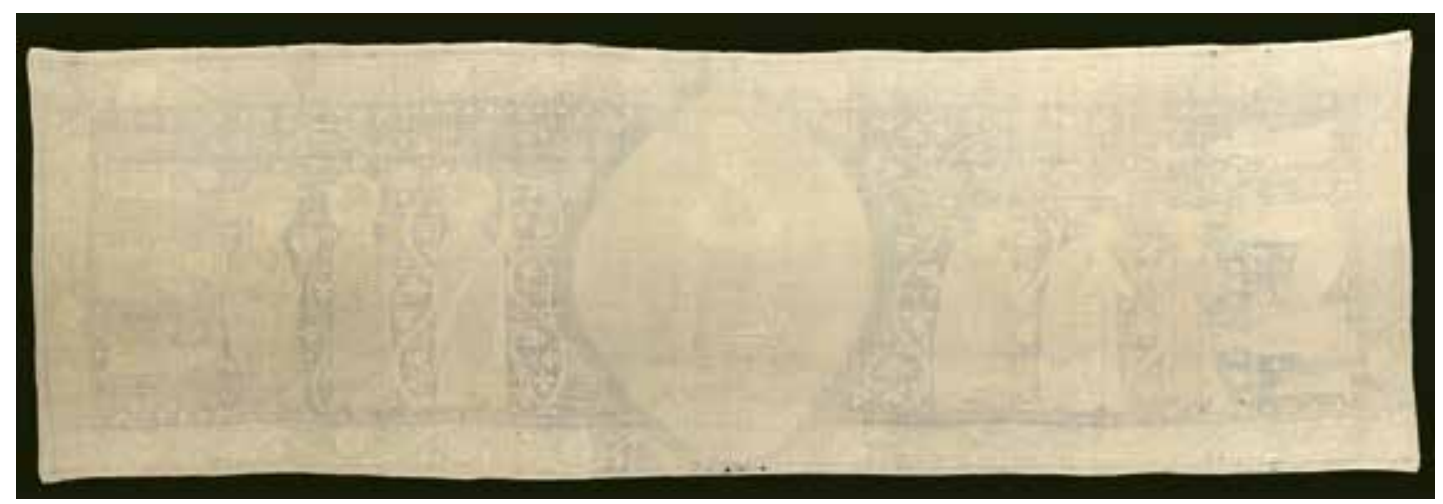

Fig. 14. Mantel de altar de Altenberg. The Metropolitan Museum of Art. MMA 29.87. (C) The Metropolitan Museum of Art. Con permiso.

cuadernación de lujo. No obstante, sin poder caracterizarlas como personajes santos, nada impide suponer que esos documentos sean de contenido diplomático. De hecho, sus retratos se antojan más afines a los de las infantas del Tumbo A compostelano (Santiago de Compostela, Archivo de la Catedral, ACS CF 34, f. 34v.) y a los de algunas de las reinas asturleonesas del Liber Testamentorum Ecclesiae Ovetensis (Catedral de Oviedo, Ms. 1, f. 18v.), dónde la fórmula iconográfica, con los personajes sosteniendo un pergamino a modo de cartela, aludía metafóricamente a las donaciones con que habían dotado esas sedes. ${ }^{36}$

Recientemente Robert Maxwell ha insistido en la importancia de la introducción de la cultura textual en los retratos de donantes con el objetivo de convertir esas imágenes en una suerte de "record-keeper", es decir, en un instrumento que garantizaba el recuerdo de una donación sin tener que depender de la memoria escrita o la transmisión oral. ${ }^{37}$ Parece lógico pensar, por tanto, que las mujeres del estandarte con sus atributos estarían evocando algunas ofrendas que realizaron a favor de la sede urgelitana y quizá, según indicaría el posible retrato de san Ot, ciertas donaciones que concedieron para respaldar su canonización (1133). En todo caso, este recurso visual proporciona al retrato de donantes una connotación adicional a la piadosa, más propagandística. Está así en línea con el tipo de vocabulario epigráfico e iconográfico de otras obras como la Estola de Leonor de Castilla de San Isidoro de León (1197) [fig. 15]. La estola se decoró con una serie de escudos de armas que acompañan a la inscripción: “+ ALIENOR REGINA CASTELLE + / +FILIA HENRICI REGIS ANGLIE/ + ME FECIT + SVB ERA MCCXXXV ANNOS" (Leonor reina de Castilla, hija de Enrique Rey de Inglaterra, me hizo en la era 1235). Con una finalidad divulgativa, como bien ha estudiado Jitske Jasperse, fueron pensados para que la reina pudiera comunicar su estatus regio y familiar. La confección de la estola mediante la técnica del telar de tabletas, empleada habitualmente tanto en el ámbito monástico como aristocrático, ha hecho pensar que la reina pudiera haber sido, al mismo tiempo, tanto responsable de la promoción como de la ejecución material de la estola. ${ }^{38}$

A diferencia de este tipo de obras con recursos textuales o visuales que hacen referencia explícita a las donantes y/o artistas, en la Estola de San Narciso, la ausencia de autorretratos o retratos de donantes complica la interpretación unívoca de su firma. Aún así, el epígrafe con "me fecit", al formar parte de una inscripción más extensa, es bastante informativo. Anscari Mundó detectó que ciertos versos de la estola parafraseaban las conocidas Laudas Hincmari, es decir, la colección de laudas que se asocian a los ordines de coronación de reinas compuestos por Hincmar de Reims $(† 882)$. Como tal, dichas laudas eran parte de la liturgia en las ceremonias de coronación imperiales y reales carolingias. ${ }^{39}$ Para comprender el trasunto ideológico detrás de estos versos y, con ello,

\footnotetext{
${ }^{36}$ Wearing, 2016: 76-106.

37 Maxwell, 2018: 259-277.

38 Jasperse, 2017: 10-13.

${ }^{39}$ Mundó, 1994: 144, 160.
} 


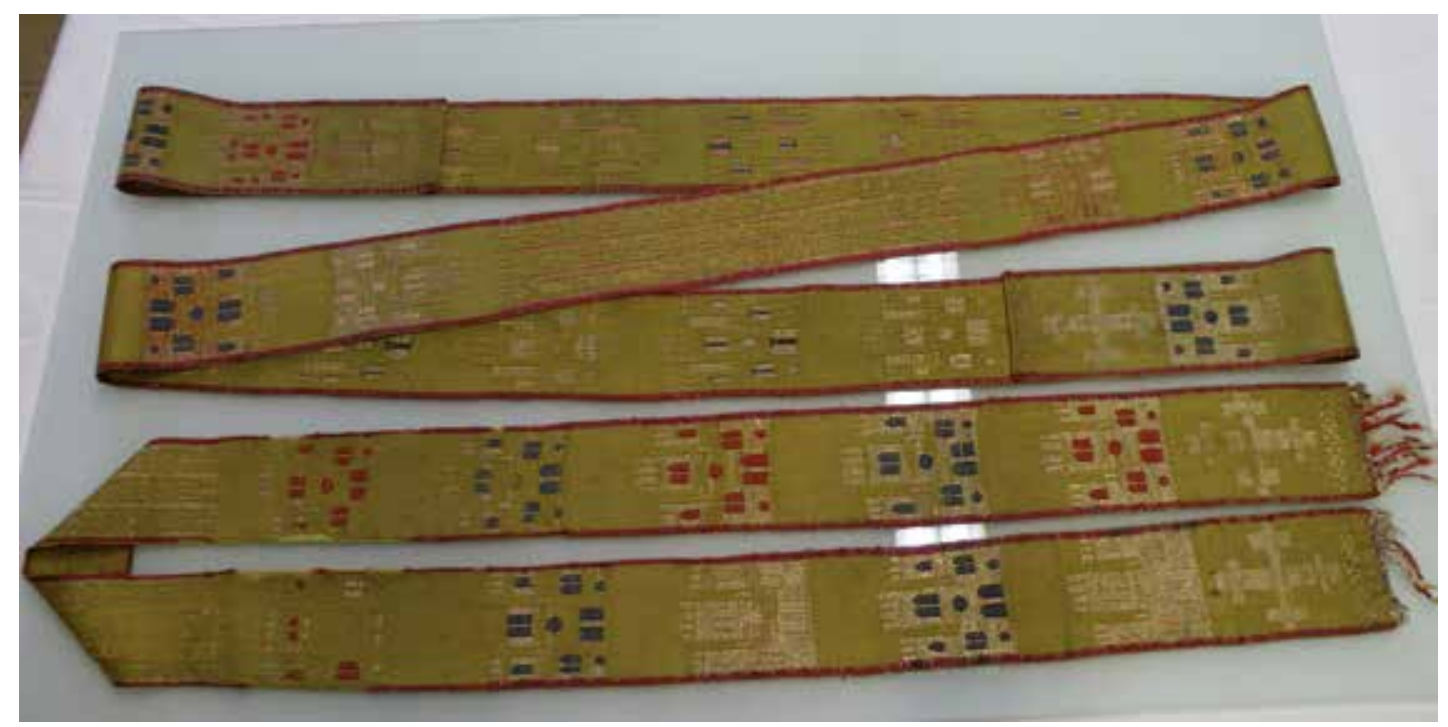

Fig. 15. Estola y manípulo de Leonor de Castilla. León, Museo de la Real Colegiata de San Isidoro. C Therese Martin.

los motivos para que se integraran en la inscripción de la estola, conviene recordar una de las imágenes que, evocando uno de esos ritos, representa el simbolismo detrás de esos versos. El retrato miniado de la reina Aelfgyfu y de su marido, el rey Cnut, en el Liber Vitae de Winchester (c. 10201030) (The British Library, Stowe Ms. 944, f. 6r.) consiste en una escena de coronación dónde la Virgen y dos ángeles, a través de la imposición de la corona y el rito de la velatio, conceden sanción divina a sus obligaciones como buena esposa y buen gobernante. Esta ceremonia de la imposición del velo fue ya conceptualizada por Tertuliano (c. 160-220) en su De virginibus velandis y, en la Edad Media, no solo se convertirá en parte del rito de consagración pública de la monja, sino también en símbolo de su virtud como perfecta sponsa Christi ${ }^{40}$ Por ello, como dedujo Dominique Iogna-Prat, lo que refleja la miniatura inglesa es un intento alegórico de asimilar a la reina Aelfgyfu, a través del exemplum de la Virgen, con una famula o esposa de Cristo, sugiriéndose que su comportamiento como cónyuge y consorte debe ser equiparable al de las monjas ${ }^{41} \mathrm{Si}$ los versos de la estola se interpretan a partir de este tipo de lectura simbólica se refuerza la asociación de su autoría con el mundo conventual. Al mismo tiempo, la representación preeminente de la Virgen junto a la firma en cuestión serviría para legitimar, con su ejemplo, la propia acción creativa de las religiosas que confeccionaron y/o promocionaron la creación de la estola.

\section{La cuestión de su autoría: el anonimato, la creación colectiva y el culto a los santos}

Tras investigar en profundidad la documentación de la basílica gerundense, de la catedral urgelitana y de los diversos conventos con los que se ha relacionado la ejecución material de las obras, -incluidos sus respectivos abaciologios-, la falta de pruebas documentales que permitan conectar la autoría de los bordados con alguna persona en concreto es una cuestión todavía sin resolver satisfactoriamente. Este problema llevó ya a Manuel Castiñeiras a proponer una idea sugerente sobre los nombres en ellos consignados. El autor sugiere que dichos nombres son evocativos de los nombres de la Virgen María y su prima, santa Isabel. ${ }^{42}$ Ambas eran consideras en época medieval los prototipos bíblicos por excelencia de la bordadora al haber sido responsables de la confección de la púrpura

40 Metz, 1951: 261-266.

${ }^{41}$ Iogna-Prat, 1996: 103-107.

${ }^{42}$ Castiñeiras, 2011: 38-39. 
y la escarlata para el velo del Templo de Jerusalén ${ }^{43}$. Por ello, el argumento de este autor se basaba en que, al imitarlas, la iniciativa de las bordadoras de Urgell y Girona era, en cierto sentido, santificada. La hipótesis es la más sugestiva de todas las planteadas por la historiografía. Sin embargo, la pregunta todavía por contestar es el por qué de la estrategia de recurrir a un pseudónimo sacro. Según las hipótesis que aquí se plantean, las razones se hallan detrás de las nociones de autoría colectiva y anonimato, así como del contexto de producción y recepción de las obras.

En la Edad Media, este tipo de juego ambiguo entre la creación divina y la humana será recurrente. Se preguntaba Therese Martin, por ejemplo, si en la inscripción que recorre la pila bautismal de San Pedro de Villanueva de Asturias (1114, Madrid, MAN, Inv. 50181), "+ IOHANNES ET MARIA FECERVNT HOC OPVS IN ERA MILA CLII" (Juan y María hicieron esta obra en la era 1152), las referencias a Juan y María quizá buscaban, dada la función del objeto, un querido paralelismo de los "makers", - ya fueran artífices o donantes-, con el Bautista y la madre de Dios. ${ }^{44}$ Del mismo modo cabe recordar las palabras del monje Goscelin de San Bertin (c. 1020-1107) sobre un alba bordada por Edith de Wilton (963-984) y dónde, según el cronista, la propia Edith "postrada en el lugar de la suplicante María Magdalena", besaba los pies de Cristo. Estos versos, de hecho, son rescatados por Fiona Griffiths para argumentar el deseo de Edith de participar activamente de los misterios en torno al altar que, como mujer, tenía prohibidos. ${ }^{45}$ Sería éste el mismo tipo de impulso que se encuentra detrás del capitel con la escena de la Epifanía de Saint-Pierre de Chauvigny dónde Gofridus, casi como queriendo asimilarse a uno de los tres magos, firma su iniciativa justo por encima de la escena: GOFRIDUS ME FECIT (Gofridus me hizo). En ambos casos se advierte que emulando a esos personajes sagrados conseguían, igualmente, asociar sus virtudes a sí mismos. Tras estas licencias creativas existe también un componente dogmático. ${ }^{46}$ Así, el escultor Natalis, con la inscripción sobre el tímpano de la Sainte-Trinité en Autry-Issards, "+ CUNCTA DEUS FECI. HOMO FACTUS CU(n)CTA REFECI + NATALIS ME FE(cit)" (Dios, yo hice todo. Hecho hombre, yo rehice todo. Natalis me hizo), parece traducir en piedra las enseñanzas del teólogo medieval san Buenaventura quien afirmaba que solo Dios podía considerarse verdadero creador por ser causa de la naturaleza, mientras que los artistas solo podían limitarse a modificar esa naturaleza. Así, el artista, tanto como el comitente, intenta reproducir con sus obras y con esta ambigüedad el acto de creación divina, pero no con una intención arrogante de equipararse a Dios, sino con una finalidad piadosa.

Aunque estas interpretaciones han recibido atención académica, la ambigüedad deliberada de estas inscripciones no ha sido reconocida. A veces una referencia ambigua, ya fuera visual o epigráfica, servía para conmemorar una iniciativa colectiva, especialmente, cuando con ella se pretendía no un beneficio personal sino defender una causa mayor. Tres obras estudiadas en profundidad por Stefanie Seeberg y destinadas a difundir el culto de santa Isabel de Hungría y a promover la canonización de Hildegarda de Bingen respectivamente, así lo ilustran. El primero es uno de los tejidos de finales del siglo XIII concebido para convertir el convento de Altenberg en un lugar de peregrinación y veneración de santa Isabel. Junto a una serie de escenas hagiográficas, se retrató a la santa en el acto de ser venerada por dos mujeres caracterizadas la una como monja y la otra como laica. Aunque ambas podrían representar a sus hijas Gertrudis y Sofía, la autora defiende que también podrían encarnar, como retratos tipológicos, los mundos laico y conventual dónde ambas concentraron los esfuerzos para expandir la devoción hacia su madre. Dichas imágenes acompañan, además, diversos episodios de la vida de santa Isabel dónde se retrata su tiempo como "hermana laica" en el convento de Marburg. Con ellos se ofrecía un modelo de conducta no solo para las monjas sino también para las laicas relacionadas con el convento de Altenberg. La obra en cuestión probablemente adornaba la pared del coro en ocasión de ciertas festividades, como las fiestas de conmemoración de santa Isabel y del día de la consagración. ${ }^{47}$

En este sentido, conviene rescatar nuevamente otro de los tejidos del mismo monasterio premonstratense de Altenberg, encargado también hacia finales del siglo XIII por la magistra Gertrudis y que se utilizaba para cubrir el catafalco de la reina santa. El bordado, como postula Stefanie

\footnotetext{
${ }^{43}$ Para este tipo de vinculación simbólica: Coatsworth, 1998: 8-25.

44 Martin, 2016: 6.

${ }^{45}$ Griffiths, 2011: 13.

${ }^{46}$ Mariaux, 2003: 199-214.

47 Seeberg, 2016: 142-148.
} 
Seeberg, seguramente formaba parte de un dispositivo decorativo más amplio en el que se incluía el anterior tejido y que estaba destinado a preservar la memoria de la santa y de otros parientes. Por ello se exhibía en determinados días conmemorativos instituidos oficialmente por la propia Gertrudis coincidiendo con el aniversario de sus traspasos. Eran días en los que el coro de la iglesia se abría a los laicos y los familiares podían reunirse a rezar en torno al catafalco ${ }^{48}$. La imagen que ofrecían los dos tejidos que decoraban el coro en dichas festividades no debía ser demasiado distante de la que habrían percibido los fieles de la catedral urgelitana cuando el pendón y el frontal/mantel de altar hubieran adornado el sepulcro y la capilla de san Ot en ocasión de su fiesta. Mostrados a los devotos y peregrinos en su conjunto, estos tejidos, gracias a sus retratos y sus epígrafes, alentaban la conmemoración de las comunidades laicas y religiosas que los crearon y estimulaban, a su vez, el culto a los respectivos santos.

El último de los tejidos es el llamado frontal de Rupertsberg en el que un friso de monjas, con algunas identificadas y otras representadas anónimamente, recorre el extremo inferior venerando a Cristo en Majestad y a una serie de santos, entre los cuales Hildegarda. En su caso, las anónimas religiosas representan no a ciertos personajes relacionados con la historia del cenobio, sino al conjunto de la comunidad que apoyaba el proceso para santificarla ${ }^{49}$ De hecho, este tipo de imagen en la que el santo se presenta como un ejemplo virtuoso para una comunidad monástica que impulsa su culto se reproducirá en otras obras textiles de cronología bastante más tardía. Así se ilustra, por ejemplo, en el Tapíz de Santa Walpurga del siglo XVI (München, Bayerisches Nationalmuseum, Inv. T 1806) dónde una imagen monumental de la santa titular es venerada a los pies por las figuras de una serie de monjas anónimas que aluden, de nuevo como retratos tipológicos, al convento.

En este sentido, haber recurrido al pseudónimo de la Virgen en la Estola de San Narciso y de santa Isabel en el Estandarte de San Ot permitía celebrar no una actuación individual sino colectiva y que quizá englobaba tanto a la comunidad monástica femenina como al grupo de aristócratas que se preocuparon por respaldar el fin último para el que las obras fueron confeccionadas. Tanto los retratos laterales de los gallardetes como los versos de la estola representarían tipológica y simbólicamente a esos dos grupos de laicas y religiosas. Aunque es más difícil de demostrar documentalmente en el caso de obras que, como la estola y el estandarte, se crearon entre los siglos XI y XII, la creación y promoción colectiva de obras textiles ha sido bien estudiada por la historiografía especializada no solo en estas fechas, sino también en cronologías posteriores con documentación más explícita y abundante. ${ }^{50} \mathrm{Un}$ ejemplo significativo son algunos de los tejidos estudiados por Birgitt Borkopp-Restle que decoraban ciertas capillas de la iglesia de Santa María de Danzig en Gdanzk. Ciertamente, algunos de ellos fueron encargados colectivamente por guildas o cofradías, como la capa decorada con orfrés con un ciclo hagiográfico de María Magdalena y que precisamente representaba los intereses de quienes probablemente la encargaron, la élite de marinos mercantes establecida en la ciudad. ${ }^{51}$

Aun así, todo indica que las imágenes y las inscripciones de los bordados fueron específicamente creadas para publicitar y mantener vivo el recuerdo de una causa no de signo político como la que abanderaron Gerberga o Leonor, sino religioso. Esto obliga a plantear, necesariamente, una pregunta relacionada con las funciones de la estola y del pendón: ¿qué pruebas hay de que los bordados fueron concebidos con vistas a impulsar la difusión del culto de un santo y la canonización de otro?

En el caso del estandarte, las mayores certezas se reducen al redescubrimiento del pendón en el altar dedicado al santo, a la pronta institución de su fiesta para la rápida difusión del culto, 一 solo once años después de su muerte-,$^{52}$ y a su canonización en fechas cercanas a la cronología más factible para la manufactura del bordado. Que el pendón debió colgarse estaría reforzado por "ciertos mecanismos de suspensión" que Folch i Torres observó en la obra en el momento de su hallazgo. ${ }^{53}$ Por ello, como ha sugerido Laila Monge, es posible que tanto el estandarte como el frontal/mantel de

48 Seeberg, 2019: 49-64.

49 Seeberg, 2012: 355-391.

${ }^{50}$ Estudios recientes han abordado intensamente esta cuestión: Schulenburg, 2009: 83-110, esp. 84; Seeberg, 2014.

${ }^{51}$ Sobre esta capa y otras vestimentas litúrgicas del tesoro de Santa María de Danzig encargados colectivamente: Borkopp-Restle, 2019.

52 Villanueva, 1803-1852 (2001), XI: 38-39.

${ }^{53}$ Folch i Torres, 1915-1920: 756. 
altar en el Victoria and Albert Museum tuvieran como finalidad vestir el altar de san Ot y la capilla durante la celebración de algunas fiestas canónicas. ${ }^{54}$ Servirían así, además, desde el momento de exhumación del cuerpo como una suerte de marcador topográfico de las reliquias.

En cuanto a la estola, se puede suponer que fue concebida como ajuar funerario de san Narciso pues Folch i Torres la localizó envolviendo justamente sus restos. Ciertos aspectos relacionados con la iconografía invitan a pensar, sin embargo, que justo antes de depositarse junto al cuerpo santo, - finalidad última para la que habría sido confeccionada - , fue vestida por un presbítero en una ocasión especialmente connotada. Se trataría de una ceremonia que habría formado parte del conjunto de acciones que se llevaron a cabo en tierras catalanas en la primera mitad del siglo XI para simular la inventio de los restos de san Narciso y, con ello, para impulsar en estas geografías la difusión de su culto. Ciertamente, fue Anscari Mundó quien determinó que para las fechas de creación de la estola se estaría gestando en la ciudad de Girona un proceso que debía facilitar la institucionalización de su culto. Las acciones que, junto a la confección de la estola, habrían contribuido a ese proceso son la dedicación a san Narciso de la iglesia de Sant Feliu y algunos de los actos de Oliba, abad de Ripoll y de Cuxà y obispo de Vic (1008/1009-1046, 1017/1018-1046). El primero remite al depósito en 1032 de sus supuestas reliquias en uno de los altares de la basílica de Santa Maria de Ripoll y del que da fe el famoso Sermón de las reliquias ${ }^{55}$ El segundo nos traslada a un momento difícil de determinar fechado entre 1038 y 1043, en que el obispo-abad visitó Girona en el día de la festividad de san Narciso; ocasión en la que recitó un sermón que tenía como protagonista al santo.

La ausencia de una tradición iconográfica ligada a san Narciso estaría justificada por la reciente implantación de su culto en estas tierras, justo en la época de confección de la estola. Explicaría, además, que se optara por imágenes relacionadas con otro santo. De hecho, la elección de san Lorenzo para decorar una obra que debía destinarse a otro santo es la que permite conjeturar que, justo antes del depósito del bordado en el sepulcro de san Narciso, fuera vestida precisamente por un prelado. Las claves se descubren en la inscripción que flanquea la escena del martirio. Allí se lee un escueto "LEVI/TA LAU/RENCI/vs" (Lorenzo levita). Por tanto, se pone el acento en su ministerio. Es posible, en consecuencia, que el epígrafe se orientara al primer receptor de la estola y, en particular, a un diácono o un presbítero que debiera, por emulación, asemejar con sus acciones las probidades de san Lorenzo. De hecho, uno de los fragmentos epigráficos de la estola, (vid) "EAS AMICE MARIA ME FECIT QUI ISTA STOLA PORTAUERIT SUPER SE ORAD PRO ME" (recuerda amigo María me hizo. Quien esta estola lleve sobre de sí, rezad por mi alma) parece invocar literalmente a dicho presbítero solicitando su intercesión. En realidad, ese mismo verso de la estola reclamaba la conmemoración por parte del presbítero, - el portador temporal de la misma-, de las religiosas y, simultáneamente, la intercesión a favor de esa misma comunidad de monjas bordadoras por parte del receptor final, san Narciso. En todo caso, como revelan una serie de mitras de procedencia inglesa y de finales del siglo XII con la decoración consagrada a santo Tomás Becket, la inclusión de escenas del martirio de san Esteban y san Lorenzo en este tipo de vestiduras proporcionaba a sus portadores un modelo de conducta virtuoso. ${ }^{56}$

Sin dudar de que, a posteriori, la estola se depositara junto a los supuestos restos del santo, la ocasión más oportuna para que dicho clérigo hubiera vestido la Estola de San Narciso debería ser una que, ensalzando a san Narciso, participara de ese proceso de implantación y divulgación de su culto en tierras catalanas. Parece plausible que esta ocasión coincidiera con la visita de Oliba a Girona el día de la fiesta de san Narciso. Como señaló Manuel Castiñeiras, los versos del sermón recitado aquel día por el obispo-abad podrían aludir a la propia estola. ${ }^{57}$ De hecho, no puede descartarse que esa celebración pública de la festividad del santo formara parte del proceso de institucionalización del culto y que culminara con el depósito del bordado en el propio sepulcro.

${ }^{54}$ Monge, 2014: 9-25. Como en el resto de Europa, también en el Nordeste peninsular será habitual, en este momento, la confección e importación de conjuntos completos de indumentaria clerical que integran el ajuar de los santos locales. De entre los diversos ejemplos procedentes de varios tesoros eclesiásticos de tierras catalanas y aragonesas, uno más o menos coetáneo, es el ajuar de San Ramón de Roda de Isábena. Para el estudio más reciente: Feliciano, 2019: 289-318.

55 Villanueva, 1803-1852 (2001), VIII: 213.

56 Vogt, 2010: 117-128.

${ }^{57}$ Una transcripción de los versos en: Castiñeiras, 2011: 37. 
La estrategia de colocar la autoría de la estola bajo el anonimato a través del pseudónimo sacro sirve para hacer pasar el bordado por una obra creada por manos no humanas, como si hubiera sido bordada por la propia Virgen. Uno de los milagros recogidos en las Cantigas de Santa María (Cantiga 2, Madrid, Biblioteca del Monasterio de San Lorenzo de El Escorial, MS T.I. i, f. 6v.) evidencia la existencia de una tradición teológica según la cual solo las vestimentas tejidas por mujeres de la órbita sagrada eran adecuadas para ser vestidas por los santos. De hecho, este milagro, conocido como del alba de san Ildefonso, fue ilustrado en un orfré bordado del siglo XIV con imágenes derivadas de las propias cantigas (Riggisberg, Abegg-Stiftung, Inv. 182). En uno de los medallones se representa la aparición de la Virgen al santo, a quien entrega el alba que ella había tejido en el Paraíso y que san Ildefonso debía vestir durante la celebración de la Misa. ${ }^{58}$ Así, dicha estrategia podría formar parte de ese proceso de ritualización con el que, en la primera mitad del siglo XI, se articuló la difusión del culto a san Narciso en Cataluña. Y, es que, podría responder a la voluntad de recrear una retórica visual de santidad, convirtiendo la estola, a ojos de los que no estuvieron involucrados en su creación, en una reliquia del tipo brandea.

En este discurso visual y textual pensado para santificar la estola, la presencia de un epígrafe o retrato auto-representativo que hubiera elogiado explícitamente a la comunidad de monjas bordadoras habría desmitificado ese proceso milagroso de redescubrimiento del cuerpo. Además, la construcción de ese mismo tipo de retórica en la que imágenes y textos se ponen al servicio de conferir una apariencia de santidad a las obras que los incorporan justificaría, igualmente, la adopción de un pseudónimo sacro para rubricar el Estandarte de San Ot, sobre todo de haber existido una cierta premura, por parte de sus creadoras, por acelerar su canonización. La elección, en su caso, de un pseudónimo que refiere no a la Virgen sino a santa Isabel tampoco contradice la intención de santificar el pendón. Para los teólogos medievales, -incluso de la tradición hebrea-, tanto su prima como otras vírgenes y célebres mujeres del Antiguo Testamento, como Esther, eran responsables de la tintura escarlata de las cortinas del Templo. Para un espectador medieval, la exegesis del Protoevangelio de Santiago $(10,2 ; 12,2)$ y del Pseudoevangelio de Mateo $(8,4-5)$ convertía a todas esas santas mujeres en un modelo de virtud para las mujeres que desempeñaban el arte de la aguja. ${ }^{59}$

Una leyenda asociada con Tomás Becket y traída a colación por Maureen Miller en su reflexión sobre el trasunto teológico tras la manufactura medieval femenina de indumentaria litúrgica y vestimentas clericales subraya cómo el anonimato podía resultar, en todo caso, un recurso útil a las mujeres. Sobre todo, habida cuenta de la compleja relación que, desde el punto de vista espiritual, se imponía entre ellas y los destinatarios de dichas vestiduras. ${ }^{60}$ Recogida por el dominico Tomás de Cantimpré (1201-1272), la historia habla de cómo el santo arzobispo de Canterbury se encuentra en la necesidad de remendar la camisa que vestía secretamente bajo sus vestiduras eclesiásticas. Lo más significativo, sin embargo, es cómo el relato abunda en el deseo explícito del santo de que nadie más que la Virgen, quien milagrosamente ya en una ocasión anterior se le había aparecido para hacerle cierto remiendo, reparara sus prendas.

\section{Conclusiones}

Al rubricar la autoría de los bordados a través de un pseudónimo que hace referencia a dos personajes sagrados, las inscripciones de la Estola de San Narciso y el Estandarte de San Ot se convierten en un mecanismo inclusivo especialmente adecuado para aludir a varias autoras en obras como estas, seguramente de creación y patronazgo colectivos. A su vez, dichos pseudónimos contribuyen a conferir un halo de santidad a las propias obras. La confección de vestimentas clericales y obras de indumentaria litúrgica medievales destinadas a los santos no requería per se de dicho recurso. Es muy posible, sin embargo, que el pretexto de impulsar y acelerar dos causas específicas relacionadas, precisamente, con la santificación de sus destinatarios como habrían sido la difusión del culto a san Narciso y la canonización de san Ot, sirviera justamente de acicate para

\footnotetext{
58 Sobre este orfré: Wetter, 2010: 89-99.

${ }^{59}$ Hollender, 2016: 570-571.

${ }^{60}$ Miller, 2014: 150.
} 
ello. La voluntad de apoyar esta última iniciativa quedaría reflejada, además, gracias a los retratos tipológicos de los gallardetes del pendón. Con ello, parece más cuestionable priorizar de manera generalizada un método de interpretación para las inscripciones con me fecit y los retratos de donantes que conlleve la identificación unívoca del autor con un sujeto histórico concreto. De hecho, se pone de manifiesto la necesidad de explorar rutas alternativas de investigación que abunden en los contextos de creación de las obras y, por tanto, en los modos específicos de pensamiento religioso y funcionamiento social de los creadores medievales.

\section{BIBLIOGRAFÍA}

Barral, Xavier (2009): “Tessuti intorno all'altare. A propósito del ricamo del Victoria and Albert Museum di Londra”. En: Hortus Artium Medievalium, 15, 2, pp. 271-281.

Batlle, Carme (1980): “La Seu d'Urgell a la segona meitat del segle XIII, segons els testaments". En: Urgellia, 2, pp. 369-417.

Borkopp-Restle, Birgitt (2019): Der Schatz der Marienkirche zu Danzig: liturgische Gewänder und textile Objekte aus dem späten Mittelalter, Affalterbag: Didymos Verlag.

Castiñeiras, Manuel (2011): El Tapiz de la Creación, Girona: Capítol de la Catedral de Girona.

Clara, Josep (1981): “L'ex-col·legiata de Sant Feliu de Girona i la guerra civil”. En: Revista de Girona, 97, pp. 251-260.

Coatsworth, Elizabeth (1998): "Cloth-making and the Virgin Mary in anglo-Saxon Literature and Art". En: Owen-Crocker, Gale/Graham, Timothy (eds.): Medieval Art: Recent perspectives. A Tribute to C. R. Dodwell. Manchester: Manchester University Press, pp. 8-25.

Coatsworth, Elizabeth / Owen-Crocker, Gale (2018): Clothing the past: surviving garments from early medieval to early modern western Europe, Leiden: Brill.

Favreau, Robert (1999): “Commanditaire, auteur, artiste dans les inscriptions médievales”. En: Zimmermann, Michel (ed.): Auctor et Auctoritas. Invention et conformisme dans l'écriture médiévale. Actes du colloque tenu à l'Université de Versailles-Saint-Quentin-en-Yvelines (14-16 juin 1999). Paris: École des Chartes, pp. 37-59.

Farmer, Sharon (2017): The Silk Industries of Medieval Paris. Artisanal Migration, Technological Innovation, and Gendered Experience, Philadelphia: University of Pennsylvania Press.

Feliciano, María Judith (2019): "El corpus epigráfico de los tejidos medievales en Iberia". En: Rodríguez Peinado, Laura / García García, Francisco de Asís (eds.): Arte y producción textil en el Mediterráneo Medieval, Madrid: Polifemo, pp. 289-318.

Folch i Torres, Joaquim (1915-1920): “L'estendard de Sant Ot”. En: Anuari de l'Institut d'Estudis Catalans, 6, pp. 755761.

Gajewski, Alexandra / Seeberg, Stefanie (2016): "Having her hand in it? Elite women as 'makers' of textile art in the Middle Ages". En: Journal of Medieval History. "Me fecit". Making Medieval Art (History), special issue, 42, 1, pp. 26-50.

Griffiths, Fiona (2011): “'Like the Sister of Aaron’: Medieval Religious Women and Liturgical Textiles”. En: Melville, Gert / Müller, Anne (eds.): Female Vita Religiosa between Late Antiquity and the High Middle Ages: Structures, Norms and Developments. Zurich: LIT-Verlag.

Guardia, Milagros / Mancho, Carles (1996-1997): "Consideracions a l'entorn dels teixits brodats catalans de l'alta edat mitjana”. En: Annals de l'Institut d'Estudis Gironins, 38, pp. 1455-1479.

Gudiol i Ricart, Josep / Ainaud, Joan / Alcolea, Santiago (1955): Arte de España. Cataluña. Barcelona: Seix Barral.

Iogna-Prat, Dominique (1996): "La Vierge et les ordines de couronnement des reines au IX ${ }^{\mathrm{e}}$ siècle". En: Iogna-Prat, Dominique / Palazzo, Eric / Russo, Daniel (eds.): Marie. Le culte de la Vierge dans la société médiévale, Paris: Beauchesne, pp. 100-107.

Jasperse, Jitske (2017): "Matilda, Leonor and Joanna: the Plantagenet sisters and the display of dynastic connections through material culture". En: Journal of Medieval History, 43, 1, pp. 523-547.

King, Donald (1970): “Medieval and Renaissance embroidery from Spain”. En: Pope-Hennessy, John (ed.): Victoria and Albert Museum. Yearbook 2, London: Phaidon, pp. 55-64.

Mariaux, Pierre Alain (2003): “Quelques hypothèses à propos de l'artiste roman”, En: Médiévales, 46, pp. 199-214.

Mariaux, Pierre Alain (2012): "Women in the Making: Early Medieval Signatures and Artists' Portraits (9 ${ }^{\text {th }}-12^{\text {th }}$ c.)". En: Martin, Therese (ed.): Reassessing the Roles of Women as 'Makers' of Medieval Art and Architecture, Leiden: Bril, I, pp. 393-428.

Martin, Therese (2012): "Exceptions and Assumptions: Women in Medieval Art History". En: Martin, Therese (ed.): Reassessing the Roles of Women as 'Makers' of Medieval Art and Architecture, Leiden: Brill, I, pp. 1-35.

Martin, Therese (2016): "The Margin to Act: A Framework of Investigation for Women's (and Men's) Medieval ArtMaking”. En: Journal of Medieval History. “Me fecit”. Making Medieval Art (History), special issue, 42, 1, pp. 1-25.

Martín i Ros, Rosa Maria (1991): "Sant Feliu de Girona". En: Catalunya Romànica, Barcelona: Fundació Enciclopèdia Catalana, V, pp. 148-149.

Martín i Ros, Rosa Maria (1992): "Penó de Sant Ot”. En: Guardia, Milagros / Dalmases, Núria / ESPAÑOL, Francesca (ed.): Catalunya Medieval. Barcelona: Lunwerg, pp. 54-55. 
Martín i Ros, Rosa Maria (1997): "Frontal brodat de la Seu d'Urgell”. En: Catalunya Romànica, Barcelona, Fundació Enciclopèdia Catalana, XXVI, pp. 425-426.

Maxwell, Robert (2018): "The "Literate" lay donor: textuality and the Romanesque patron". En: Camps, Jordi / Castiñeiras, Manuel / McNeill, John / Plant, Richard (eds.): Romanesque patrons and processes, London-New York: Routledge, pp. 259-277.

Metz, René (1951): "Les conditions juridiques de la consecration des vierges dans la liturgie latin. Des origines à nos jours". En: Revue de Droit Canonique, 1, pp. 261-280.

Miller, Maureen (2014): Clothing the Clergy. Virtue and Power in Medieval Europe, c. 800-1200. Ithaca-London: Cornell University Press.

Mineo, Émilie (2018): "La mémoire nominale des artistas dans les abbayes romanes". En: Les Cahiers de Saint-Michel de Cuxa, 49, pp. 231-242.

Monge, Laila (2014): “El estandarte y el frontal de sant Ot: ¿El ajuar del santo obispo de la catedral de la Seu d'Urgell?”. En: Anales de Historia del Arte, 24, pp. 9-25.

Mundó, Anscari (1974): "L'Autenticitat del Sermó d'Oliba de Vic sobre Sant Narcís de Girona". En: Annals de l'Institut d'Estudis Gironins, 22, pp. 97-114.

Mundó, Anscari (1994): "La cultura artística escrita”. En: Catalunya Romànica, Barcelona: Fundació Enciclopèdia Catalana, I, pp. 133-162.

Pujol i Tubau, Pere (1922): "L'església de la Pietat, de la Seu d’Urgell”. En: Analecta Sacra Tarraconensia, 5, pp. 331352.

Rodríguez Peinado, Laura (2020): "Indumentaria y actividad textil femenina en los siglos del románico". En: Huerta, Pedro Luis (ed.): Féminas. El protagonismo de la mujer en los siglos del románico. Aguilar de Campoo: Fundación Santa María la Real, pp. 227-253.

Hollender, Elisabeth (2016): "The Depictions of Esther in Piyyut and Ashkenazic Piyyut". En: Cordoni, Constanza/ Langer, Gerhard (ed.), "Let the Wise Listen and Add to Their Learning" (Prov 1:5). Festschrift for Günter Stemberger on the Occasion of his $75^{\text {th }}$ Birthday, Berlin-Boston: De Gruyter, pp. 557-574.

Seeberg, Stefanie (2012): "Women as Makers of Church Decoration: Illustrated Textiles at the Monasteries of Altenberg/ Lahn, Rupertsberg, and Heiningen (13th-14th c.)". En: Martin, Therese (ed.): Reassessing the Roles of Women as 'Makers' of Medieval Art and Architecture, Leiden: Brill, I, pp. 355-391.

Seeberg, Stefanie (2014): Textile Bildwerke im Kirchenraum: Leinenstickereien im Kontext mittelalterlicher Raumausstattungen aus dem Kloster Altenberg/Lahn, Petersberg: Michael Imhof Verlag.

Seeberg, Stefanie (2016): “The Imagery of the Altenberg High Altar”. En: Heaven on Display. The Altenberg Altar and Its Imagery. Exhibition Catalogue, Städel Museum, Frankfurt am Main, 22/06-25/09 2016, Berlin-München: Deutscher Kunstverlag, pp. 142-148.

Seeberg, Stefanie (2019): "Paramente als Mobile Bildträger Im Bezugssystem Der Mittelalterlichen Kirchenraumausstattung. Das Altenberg Altarensemble und die Elisabethkasel in Erfurt”. En: Röper, Ursula / Scheuer, Hans (eds.): Paramente in Bewegung. Bildwelten liturgischer Textilien (12. bis 21. Jahrhundert), Regensburg: Verlag Schnell \& Steiner, pp. 49-64.

Schulenburg, Jane Tibbetts (2009): "Holy women and the needle arts: piety, devotion, and stitching the sacred, ca. 5001150". En: Smith, Katherine Allen / Wells, Scott (eds.): Negotiating community and difference in medieval Europe: gender, power, patronage and the authority of religion in Latin Christendom, Leiden: Brill, pp. 83-110.

Tomàs, Pilar (1956): Estola de Sant Narcís, Barcelona: Arxiu del Museu Tèxtil i d'Indumentària de Barcelona.

Villanueva, Jaime (1803-1852): Viage literario á las iglesias de España, Madrid: Imprenta de la Real Academia de la Historia.

Vogt, Caroline (2010): "Episcopal Self-fashioning: The Thomas Becket Mitres". En: Wetter, Evelin (ed.): Iconography of Liturgical Textiles in the Middle Ages, Riggisberg: Abegg-Stiftung, pp. 117-128.

Wearing, Shannon (2016): "Holy donors, mighty queens: imaging women in the Spanish cathedral cartularies of the long twelfth century". En: Journal of Medieval History. "Me fecit". Making Medieval Art (History), special issue, 42, 1, pp. 76-106.

Wetter, Eveline (2010): "Defining a Model of Worship: An Embroidered Orphrey with Depictions Based on the Cantigas de Santa María". En: Wetter, Evelin (ed.): Iconography of Liturgical Textiles in the Middle Ages, Riggisberg: AbeggStiftung, pp. 89-99.

Fecha de recepción: 31-V-2021

Fecha de aceptación: 26-VII-2021 